\title{
Universal Economic Plan Based Law Constitutions of Kingdom and Nations
}

\begin{abstract}
Mesut KAVAK*
In this work, touched on some social issues whatever the result, and a raising awareness was aimed by some new technological upgrades for the vital infrastructures of states, social order and economic plans. The main aim is one world order which has no king and accepts nations as local governance as a requirement of hierarchical order. It is completely based on economic benefits of all nations as there is no alternative to establish a healthy economic order as economic management is directly related with laws. As the important is a law exists or not, or is just or not for justice, also it encourages to develop organic laws in state institutions as it recognizes any state institution as autonomous. No state has this constitution. This work is only an offer.
\end{abstract}

\section{Introduction}

The purpose of life is living in peace and providing possibility oneself. Also every action creates a law. For example, when you head for a person, then it means a law is going to emerge between you and the person; so as a requirement of this, for example, you cannot lie to that person or you cannot make a bad decision if you do not know anything about this person. If you enter a foreign land to make a war, then there is going to be counted as your land without looking at the war result. If you win the war, really there is going to be your land. If you plunder the land, rape the women or enslave all the people there, then you become a traitor. Law is pretty exact even we know, do not know or interpret it wrong manner as a requirement of the conservation of information, as law is inevitable in any act that information is included as well because of the polarized structure of existence.

If this is the situation, then as there is always going to be a law which is able to emerge between institutions, states and even in family, also to realize the main aim, certainly and naturally a law is going to emerge between the nations which wish to live together and had been determined their borderlines. This situation actually is not an obstacle against behaving as a single civilization and to be connected to the same rules, when we looked at the law multitude and diversity which emerge during acts.

\section{The Kingdom Constitution}

Kingdom constitution is a state constitution. These laws are the laws that it is not suitable to change them continual manner, required vote majority of the people, and as constant criticism is not suitable for consultation proprieties also it includes crime. These laws are the most basic and general law principles as they are the sum of the functions which the state handles over them. Some laws which make sense with these laws and are supportive should be examined under organic or organelle laws title as special law principles as they always open for changing and improving frequently only because of methodological reasons. Organelle laws belong to the state organs since state consists of state organs.

\subsection{The laws about the general shape of the state}

This state is a kingdom.

Article 1

\section{The reason}

Self-regulation of people and democracy are not only limited by a republic. When to be directly connected to the people and the managers of the management is taken, to be contaminated in the point of etymology or to be known only by some different mind and regulation based managements of management style is always probable. As there is an end for changing managements because of unlike-able experiences, also we cannot reach anywhere by these changing. Wrong managements can be corrosive and destructive for people as people live for peace, because of the famous hostilities of people which are caused by the own creation of human since political party itself which is the medicine selected to heal people for regulation can easily cause unfriendly polarization which made hostility ahead instead of service, tendency of to be leader, emerging lies which are because of service duration and insufficiency of infrastructure, disconnection between parliamentarian and people, and to be abused by foreign states, companies and people. As there are always some certain prevention against like these negativenesses in the posture of states, also the main expectation is not voluntariness. State does not have to spend time for you and search you about it, that are you an ignorant or willful enemy.

People always need education. As they think simple, also their main work is not interpreting yesterday, today and future by some historical, philosophical, administrative and other technical information. I do not say this to condemn them. A medical doctor does not have to know about philosophy. Management is a work in itself; so you cannot wait for management from people as their main work is not management. Moreover, many times they can claim right unlined manner; so people should know, that if to be optimistic does not provide benefit, then to be pessimistic never provides; thus they should always be optimistic, should not make paranoiac jurisprudence or decisions, and they should take a leadership help as became freed of polyphony manner by right delegations. They should search for ways of managing oneself as inactive manner like a boss. When they looked at past from future, they should decide to their own heroes themselves.

Already any required information for managing of a state with its all elements exists, and is in the medium. A new financial management or state order is not going to emerge tomorrow. We cannot wait for emergence of a hero by the way of current democracy as we do not need already. A state order which is not written by the right functions with its all elements is able to improve its own possibilities and abilities 
autonomous even while providing what they want for the people want to be busy with politics at that time being more than enough satisfying. To realize this, we do not need politics like current ones as also actually the thing which is waited for healing can cause troubles in people. Any body but some natural special conditions if obtains enough vote by the elections done any time without political party, can start the work quickly. If it is for a new king, just a 'congratulations' is enough, that maybe additionally a formal ceremony is realized. This also will block othering in society.

The king shall only be elected from nobles of the basic race.

Article 2

\section{The reason}

If nobles are not cruel persons, they always become the persons which people always show respect for them willingly. As they are used as leaders, also they are used as referee by people. If there is no social corruption, then if nobles do not fall in arrogance, their places in people sight do not change. People should know, that kings are a shield against social corruption and hostility of managers, and they should not pay a compliment more than king's right for any person who causes good and big works. As everybody cannot do everything, already important things are waited for from important people.

The religion is the religion has been declared. The state does not recognize sect.

Article 3

\section{The reason}

Religion is not a thing which can be escaped because of its nature. Religion is the sum of the laws which emerge in any area in society. Also state is a benefit company which is dependent of two basis as voluntariness and sacrifice; so it cannot be created a second concept like state which is independent of people and laws.

There is no other method to transport information from today to future. It can only be transported to future by people and by the way of rumor. Naturally it may cause different jurisprudence, and a certain line may not be drawn between people. At this situation, the information which are known as right by exact evidences are accepted. People can use any different information by changing them constantly or they always use one of them.

The basis is hierarchical order in people, state institutions or private institutions. The state uses special or general titles for this reason.

Article 4

\section{The reason}

If people are always together with learning need, and if they always realize it from infancy to old age, it means that there will always emerge some groups like experienced and more experienced. If the main aim is learning, then the experience difference between these groups creates a teacher-student law spontaneously. Also in the point of the requirement of to be or looking for an interlocutor to stay away from polyphony for spontaneous emergence of the leaders who represent the groups which a exact company was created finally by providing consensus or because of the rules as an obligation or by some sacrifices in it, is the most suitable as it is inevitable for the groups or the interlocutor.
Speaking, writing and worship languages are the formal language has been declared. The only single language learning of it is an obligation is the formal language.

Article 5

\section{The reason}

As states are social establishments, to emerge of agreement and contact in any area, certainly the state has to have only one common formal language.

There is no language obligation in the structure of religion. There is no holy language but there is a prophet in the story, as a courtesy. The main expectation is to understand what is done. Heavenly information have to come to place where the prophet exists in the language of the prophet naturally. There is no untranslatable word. To be untranslatable of a word renders impossible to be understood of that language. If the main text is conserved, there will no problem.

The state uses 4 basic settlement types as basic settlement elements as North State, South State, East State, and West State. There are colonies as the single settlement type have 1 million people potential with 100.000 people current. There is no district, town or village. Governors are responsible about states. There are presidential management systems for colonies.

Article 6

\section{The reason}

As required by hierarchical order, beside people also settlements should be taken to the most simple and the most efficient pieces to provide work health. A picture is perfect when you work on each pixel, and if it has enough pixels.

The name of the state is the name has been declared; its capital city is the city has been declared; its flag is the flag has been declared; its march is the march has been declared, and its emblem is the emblem has been declared.

Article 7

\section{The reason}

States should have a capital state which are taken as an interlocutor by the other states international, a flag sign of its people, a march, a name and a state emblem.

The noblest council is the Consultation Council of the king. There are communal public councils which are as regional councils in colonies, that colony president leads it. Representatives Committee is formed by the presidents of colony as Chief Constable, Head of Religious Affairs, Director of National Education, Director of Justice and Director of Finance in colony councils, as colonial ministers. The other members are elected by the people. Member number of colony council is determined by enough vote of the council members if a vote multitude is provided, and the number always can change.

Article 8

\section{The reason}

The Consultation Council is a council, that the king elects his own assistance to manage of the state. There is no limitation for the king to choose in the point of age, education, number and work time. They are actually educated special manner. 
As the king is not enough alone, he can choose infinite number of assistance.

$$
\begin{aligned}
& \text { The noblest judgment institution is the Noble Coun- } \\
& \text { cil. }
\end{aligned}
$$

Article 9

\section{The reason}

Even if any lawsuit is not in its interest area, a the most basic institution is pretty required as responsible of all of the judgment works of the state.

When it is required, the state recognizes vote majority of referendum as binding for any subject as the final decision.

Article 10

\section{The reason}

Even if the state is a kingdom because of some certain reasons, nobody has an absolute judgment authority except the people; so when the conditions determined by the constitution and organic laws matured, the people make the final decision. Otherwise, the people cannot be inclusive of the works of the statesman as also they do not be inclusive of the works of medical doctors, engineers or the other professionals.

The main educational system is half residential for primary, secondary and high education. It is an obligation, that students and teachers shall wear national dress. Education is a natural right of people. As it is an obligation for male or female, also education is free for the people provide the terms in the organic laws. The state shows respect for private schools. There are sport schools which gives education at primary school level being the lessons distributed on years due to the shape in the organic laws. Obligatory education time for female is short and is as in the organic laws.

Article 11

\section{The reason}

Emerging short education times and to be educated of the students more efficient and professional manner will always be better for them when they only have home leave in weekends in this half residential education type. The students will get used to it as all the system is the same for all of the state. For primary and secondary education, the curriculum should be simple as much as possible. Some university lessons should not be given even as an introduction. The students should learn anything in its time. They should feel need themselves for the lessons already became simple and little, and they should learn in the best manner what they learn as well by this way. We can save time by this way as well. Huge educational campuses which are actually in a small number even for countrywide that the students have any social and technological possibilities, and primary, secondary and high education schools are all together there, will be pretty efficient.

Also national dress which is as summery and winter dress is an obligation against girls who wear like randy, and also nobody should know about the other person's economic status. Also as this is requirement of respect of them for their own works, even teachers have to wear the dresses. Teachers should have different dresses for lessons, meeting and graduation.

Sport works cannot be realized as a hobby. It is very serious work like any work, and requires many years. You must take people when they are child to educate them. They do not need many intellectual information. This is not their work as they will forget them. We should distribute primary school lessons on many years. They should not be busy with lessons. This will increase the quality of football, basketball, and the other sports, and so it will increase the quality of Olympiads.

The same is acceptable for girls. They do not have to learn more than enough. There are many people waiting for school to finish of it. If the subject is teaching something to the society, you must leave utopian and perfectionist imagery; because even while you are talking about them, millions of people do not interest about that subject at that time. You can never catch the aim in your mind. While you are dealing with your idea, time is passing and you are making busy people by taking their time

By this way, also they will be far away from their families; so they will grow in an intellectual environment. This will also determine their quality. They do not learn bed things because of unqualified families. Even only duplicating is enough to progress or regress; so they will duplicate their teachers and friends. We must create an oppressive environment for them for a time. Being the same is acceptable for any work, we can say, that "no pain, then no gain".

The shape of the institutional operation, and rights and responsibilities of the responsible people are determined by the organic laws as separately in the state institutions. Contradictory precautions cannot be taken against the constitution.

Article 12

\section{The reason}

Is a law just or not, and exists or not, this is the important for justice as to be in a constitution or in a family of these laws is not important.

\subsection{The basic rights and the responsibilities of the state elements.}

\subsubsection{The rights and the responsibilities of the state}

\author{
The state waits for loyalty from its people. Unfaith- \\ fulness is treason.
}

Article 13

\section{The reason}

Against to be corrosive of the people and of the missions, any people must know, that they do a homeland service, and they must be loyal in any condition.

When the state waits for help from its people, the people have to help if they have enough power.

Article 14

\section{The reason}

Statesman is a part of people. In their missions which are done as the requirement of the state mission, help of the people is a homeland mission if statesman is just.

There is no institutional or personal action which cannot be done law court. When it is required, the state suspends constitutional rights of all the state elements.

Article 15 


\section{The reason}

In the name of to be clear, to escape responsibilities, and as the people are not perfect, lack of the person or the institution which cannot be done court is always the best attitude.

The state property is a sacred deposit. Harming them willingly is treason, and a sanction shall be made according to the classification in the organic laws.

Article 16

\section{The reason}

The state property is the people's property at last. There is no valuable people, that they harm property of the citizens by such a big disrespect against national labor.

Conservation of the religion is an obligation for the state. Head of Religious Affairs is appointed for this subject. Head of Religious Affairs is National Religion Minister.

Article 17

\section{The reason}

The most holy value of people is religion. They protect it whatever the cost. Religion must be protected against wrong information which have a potential for creating unrest. The state cannot remain indifferent about the propagating people but the believers. The state must take required precautions for any condition which is inclined to abuse.

Unlawful order and obedience are crime.

Article 18

\section{The reason}

As a natural result of emerging contrasts as required by the polarized nature of existence, any person on a line which must be chosen and must be gone on it can only make decision on a certain line, and if it is a right, they can give orders. The chief who makes an unlawful order is certainly criminal; but for the people who are responsible about the orders, we must look for were unlawful order and obedience lessons given against abuse. Unlawful order and obedience lines have to be certain for any institution. Anybody must know the mission certain manner.

The state is responsible about international laws.

Article 19

\section{The reason}

Civilization is pretty inclined for a butterfly effect in the point of strategy. Every nation is responsible about their laws, and the main expectation is not voluntariness. The people who are not volunteer have to make sacrifice.

The state cannot stipulate compulsory military service but the special conditions which were determined by the organic laws. It is an obligation for the state, that the state shall train security forces which are dependent of voluntariness basis.

Article 20

\section{The reason}

Military service is the right of the state on its people; because states are benefit partnerships. If you live in security provided by some citizens, also when the day came, you have to help your state as an obligation. Even the situation is this, we must remove armies worldwide. We can use some operational light defense soldiers in a limited number have high technology equipment. Also being under the control of the Kings Council, according to determined standards; some land, sea and air vehicles can be manufactured in a little number as support elements.

The main aim for wars is satisfy God by establishing his order; but human is not enough patient, just and heartfelt as they do not know religion enough. We always create an absolute hostility mentality by collecting revenge in the hearts and the souls of our enemies. The state maps which are one of the most changing things along the history are good examples for this.

If a prophet who lived in old ages is taken, as people may be very sensitive about this subject, the prophet cannot make notifications without guard and after that without army. Anytime a war can easily break out; but our possibilities do not require to be there for making notifications. If a prophet was in our age, he certainly would use social media and media even if still there will be a war possibility.

Making war for need of raw materials is really nonsense now as well. We can produce any matter in an electric field anywise without energy problem. We can bring some big size asteroids to world without thrust engine and energy problem. Also we can transform Mars or Venus into a livable planet without energy problem the other negativenesses are included as well $[1,2]$. We can produce water for using and drinking from air or sea, and other much more possibilities exist as well.

The Kings Council gives money for the people who want to do business. Tax is a right of the state. The workplace owners recognize the state as an absolute joint. They shall pay clearly half of their earnings without any external pays. The state can only demand tax from active business. The tax can only be shared out between inactive people by the determined shape in the organic laws. There is no exemption for the tax. It is an obligation, that the state shall limit the share of the people and give the money back to the Kings Council if the collected tax shadows the salary of workers and so if it blocks work incentives.

Article 21

\section{The reason}

Any state's own committee which works in the name of the Kings Council should give money as a grant for the people want to do business. More business means more buyer even if the productions are sold or not, the raw materials are included as well. The committees which are dependent of the Kings Council can see all of the active or passive business of the world even the smallest work places are included as well by an international database software which can be checked by anybody independent observers are included as well. Any body must know the current situation, potential, done works before, agreements, worker number and ages etc. of any work place like that work places' owners. A single cost condition will be provided for any long time and any multitude property without inflation. If there is a satisfying potential, the committees will give the money. Advertisements about required business according to the system is also mission of the committees to open new workplaces. Also they can record the names against new opened potentials to call when the day came. 
The salaries of civil servants will be paid by the Kings Council. There is no difference between state pay or council pay but a formal paper. To make simple it, it is required. The states only must pay attention about growing money back, that they are responsible about return of the money back to the Kings Council. For example, if there are some rare agricultural productions, they cannot be shared out between people, and is included to money back until production increases, and must be increased as an obligation. They will be sold, and the money will turn back to the Kings Council until that time.

As working is a conserved right by the state in private or state works, inactivity is preserved as well but the special conditions which were determined in the organic laws. For legal works, anybody can work as worker or can do own business. Nobody can be forced to work in works which are not comply with sex, age or power. Break is a right in working time. Holidays are determined by the organic laws. It is an obligation, that the state shall provide required possibilities for its people against to be in need of them even if they do not work.

Article 22

\section{The reason}

Peace level will increase in the nations that there is no economic anxiety, and anybody can do own lovely works because of an emerging big indifference about problems. If there is a peace, work quality increases absolutely as well. Also these changing will decrease crime. Increasing trust and patient of people and statesman have a strategic importance for a state. Many obstacles will occur while we are managing a state in the name of to be fair. Maybe as we will not be able to give to everybody what they want, also sometimes we cannot give the actual rights to their owners; because some works may be done according to an uncertain reference. This is never acceptable; so going from the reverse direction must be the right of people; because we cannot wait absolute discipline where there cannot be absolute fair.

As energy is not problem, also we can manufacture any building material by electric field as it was said $[1,2]$, by onetime cost. Buildings can use self-running free energy generators for any work heating and cooling are included as well. It can be used for purification of waste water, production of drinking water from sea or air.

When law courts confirms, the state shall place divorced women and family members who was exposed to domestic violence and sexual abuse to a separate house free manner. If they do not work, the state shall pay their share from taxes. For in need young people, the state shall establish an institution until the maturity time which was determined by the organic laws; then when the time comes, the state shall place them to a separate personal house, and shall give the share from the tax. The state shall build free special shelters have the required special possibilities determined in the organic laws for elderly people.

Article 23

\section{The reason}

In the base of existence of state, there is always a condition like taking reciprocal service. As people are not independent of state, states must adopt its people like a mother.
Not working should not seen as dangerous. Anything is our hands. We can extremely limit the pays for the people which are not working. They cannot live then. At that time there will no other choice than finding a job and working. If it is required, we can limit the pays. At least, people will not in need about house, communication and transportation when we limited the money. They will have enough time to seek a new job.

The state is not responsible about volunteer people for a negative result of a referendum which is done to make a war besides compulsory war condition; but when it is required, the state shall take required precautions.

Article 24

\section{The reason}

A perfect precaution may not always be possible for any work. To know states as responsible about the people who have unknown intention will be a heartlessness if they are not statesmen.

No decision is binding unless secret or public reason was declared. Secret reasons cannot be hided indefinitely.

Article 25

\section{The reason}

As people may have some illness like arrogance, envy and jealousy, also a decision without reason cannot be made. Already as required by conservation of information, any work must be able to be classified. The state can declare secret reasons strategically.

The state applies death penalty for the crimes which are determined in the organic laws. The state can take body organs of some people who carry the conditions in the organic laws without asking being the first the state benefits and as the second for international benefits.

Article 26

\section{The reason}

Death is always together with us as it is always a possibility. It does not matter for death, that you are old or young, are noble or not. It comes, does its work and leaves.

People have an absolute right about blessing of God as they wish in theory; so to get out of hand of this right requires the same event as penalty as actually it is not enough as well; because a person who is volunteer for death cannot wait for death of somebody as a provision.

In the other hand, we must take some organs of the people who are terrorists, gangsters or serial killers and rapist without asking legally. If they use our any possibility, and even so if they do not give a little benefit, then we can use their organs. We must make some families happy, that they may be offended because of some bad illnesses.

There is only one security unit which has different missions in itself. It is leaded by National Security Minister. It is an obligation, that the state shall educate National Security Minister who knows the current security system in the best manner and can manage the army to make war when it is required.

Article 27 


\section{The reason}

National security is a phenomenon alone. Police, soldier and intelligence units work for the same thing basically; so all of them should be connected to the same main unit. They can be separated technically as special force, colony, mountain, flying squad and the other ones.

No attraction center can be created except the created ones by the state according to the organic laws. There is no city center. The people have no economy right on the coastlines.

Article 28

\section{The reason}

This can block some economical fluctuations and remove the needless charge on economist. In the other hand, the big gap between people will be removed. Also it will cause expansion.

The state should create small attractive centers to be incentive of there about science and working. The coastlines can only be used as social areas and forests, and are used for high reputable people like have scholar title for luxury mansions with servants. These places cannot be used for house or business. Already each colony will have a lake big enough.

The state recognizes all of the underground and above-ground resources, and territorial waters as its own property.

Article 29

\section{The reason}

A state is state with its underground and above-ground resources, natural values and territorial waters.

Legislating, governance and judgment are not unalienable responsibilities but the units have right in the constitution. These units cannot transfer the rights unlimited and its shape is as in the organic laws.

Article 30

\section{The reason}

These functions are the most basic, serious and important functions which the state works over them; so we cannot let corruption.

The state has a space policy with its population. The state has to take required precautions for space colonies. It is an obligation, that the state shall establish hospital, health and science research centers, and shall control the any state activity on heavenly bodies which can be colonized.

Article 31

\section{The reason}

The future is in space. Science is not done only for known exact benefits. Nobody knows what will happen, that this situation is the first reason for doing science actually. When we turn back, there is nothing another thing to do.

As it was said $[1,2]$ for example, if we can find some asteroids have carbon dioxide in the space, we can easily hit at high hyper-sonic speeds them to Mars to heat there, without energy and thrust negativenesses. After that we need some other asteroids contain water, nitrogen and oxygen. Also we can use ionizing method without energy problem for water, mine and recycling. We can go to Mars in 1 week by the earth gravity manned manner even when Mars is at the furthest distance as we can go to there unmanned manner in the same day. This is not a dream, and is usual like any work.

The state waits for respect about its religion but believing. The state recognizes extremism as hate crime for any group. The state shall take required precautions about to be complied social requirement of religion, and waits for to be applied for any religion member.

Article 32

\section{The reason}

Any people absolutely wish loyalty and service for their religions. They protect themselves against foreign opinions; so as always the own religion of people will be dominant when a conflict emerged as a result of a revolt, also crime is nothing but at this situation as a revolt, and penalty is the penalty solely in this situation as well.

It is an obligation, that the state shall prepare shelter when a new person was born according to the private property living standards and the obtaining private property conditions in the organic laws.

Article 33

\section{The reason}

As stated the above and actually in the below stated sections more detailed manner, we can build some prefabricate high buildings almost from today to tomorrow by some new techniques without any other negativity like electricity, heating and cooling as free manner [1,2].

When the required infrastructure was prepared, factories can feed many other factories. This will create an employment as also we will be manufacturing for houses.

Private or general titles which are required by hierarchical order cannot be used but the owners.

Article 34

\section{The reason}

Some general titles like doctor, captain and minister; and special titles like scholar and sir must be used for people. This is required by justice. Nobody can use these titles instead of the owners.

Business is free within the framework of the constitution and the organic laws. There is no number limit for having active or passive workplace. The farmlands belong to the state. The people have no economy right on the farmlands. The state has to use continuously all of the farmlands within the framework of the constitution and the organic laws but some technical reasons. Compulsory aim for livestock and farming is to create the infrastructure for an order which provides excessive production continuously.

Article 35

\section{The reason}

The state pays for inactive people, and also gives them free houses without energy cost, heating and cooling charges are included as well. Also the state will farm professional manner by its engineers, and even if it will not prepare meal, it will provide free agricultural production enough. 
As the grant by the Kings Council, the basis is production, and also is to be able to have enough production producing potential even if they are active or passive. Anybody can have unlimited factory active or passive.

All the state elements have the same rights for justice as the same as before when they were retired or were resigned. Waiting for revenge is a serious disrespect for the holiness of justice.

Article 36

\section{The reason}

As it was said, waiting for revenge is a serious disrespect for the holiness of justice.

Money earning by interest, value change of money or value change of trade properties are forbidden. The institutions which have an economic event with people directly have to provide protection possibilities for chattels. These institutions cannot give credit with no reason given; but they can demand service fee for their services.

Article 37

\section{The reason}

Whoever the winner or the loser is, if there is a potential able to make business which is not a result of a labor, then it means the labors which are spent for the peace and the survival of the state do not reach their places. There is nothing dangerous as much as this condition for economy.

The elements have justice authority can use any number of expert as helper.

Article 38

\section{The reason}

It will be better for the decision quality and security; so it will be more satisfying. Short law court duration is always better.

Service hour is the basis for retiring. The people who already completed this limit cannot be called for compulsory service when it is required but the special conditions which are determined by the organic laws. There is no retirement bonus. Any worker formal state workers are included as well, have to be paid daily or at the end of the work parts.

Article 39

\section{The reason}

Important thing is your service hour. Maybe if there will be some worker requirements, the people can be called for the work with a shift.

Installments causes inflation even if what precautions you take, and so you always must do business by cash. It is caused especially because of the people who have no other choice to sell even if they cannot earn enough at that time. Also installments can easily be abused. It causes an imaginary money and work potential when it is used instead of cash which is return of lowered imaginary nominal value.

It is an obligation, that the state shall make settlement plan based on population being the main aim is economy, shall spread the population out according to the employment created and shall do interview for migrations between colonies. The basis is the main place of birth of the people for spreading out. Attraction centers shall be created for educated people in all of the colonies. Creating high population colonies is forbidden. The state shall determine some standards for colonies, roads, houses and sidewalks, and shall not accept the other works do not provide these standards.

Article 40

\section{The reason}

Workplace of the Kings Council grant is determined by the state according to its population plan. If the state cannot find some business men out, it appoints from its own people; because population is very dangerous in the point of security, work and people health, wars and natural disasters. The state may lose its working potential in high population cities when a natural disaster or a merciless war emerged.

Also we must determine some standards for city elements. For example, we can build prefabricated buildings almost from today to tomorrow. You can lift millions of tons by a few tons of material if you use enough surface, height and width if you knit a structure like in the below stated sections. We should build the colonies as circular by some rings have different radius for example being there is a stadium at the center of the colony. The stadium has to be enough big to take all the people of the colony, and has to be movable by the thrust engines [1,2] against disasters and wars. There may be a hospital has the same capacity with the stadium at the top of the stadium. Also there can be a flying ring near center being there is a flying skyscraper at the center of the ring. There should be 100 meters width roads by the knitting method which I told about it in the below stated sections of the article. Vehicles, car parks and other buildings and vehicles can be manufactured by the same way as bigger, as anything will get bigger to be cheap, strong and fast produce-able of them. We should build a race track which is also used for driving learning track has 200 meters width fully-closed manner, around the circular colony. As also it will be a wall, there should be 4 entrances of the colony. Anybody must be controlled at the entrances. Also we should build some squad castles according to howitzer range. As each colony is autonomous, also each colony should have a squad castle and they should only accept soldier from their own colonies. One-piece huge airports, universities, schools and other elements can be realized easily. Heating, cooling, lightning and lifting are not problem, and can be done by one-time material cost spending.

The state does not do business by interest between its institutions or international. Creating black market and doing usury are forbidden, and are crime.

Article 41

\section{The reason}

As it was said the above, interest is enemy of economy. All works of the people belong to their states already.

Black market cannot be created. Already we do not need it; because the Kings Council shall give the grant, and also nobody can say like "I won't sell it to you, I have a little or after this its cost is this." as required by the Kings Council's policy.

The state has to take required precautions to bring new technological evaluations which are gained except slow development and improving time as there is no other alternative in the point of material and method, 
to life. The state do not accept any commercial agreement for this subject; but it makes required consultations with bosses and experts as it does not allow them to lose money and to be damaged of them. If it is required, the required period is determined by the state.

Article 42

\section{The reason}

The state must follow technology, and must take required precautions to increase competition by the grants. Commercial agreements are forbidden as also it is forbidden by the Constitution of Nations. The state should plan it against business money, time and labor loss; because creating an infrastructure takes too many times as also it is expensive. Technology almost changes from today to tomorrow, and you cannot wait a change like this. Even so, any body can take money again and again if the state orders about their change. Nobody will be damaged.

Business money is under the control of the state. Chattel or real estate protector international person or institutions recognize this term. The state shall recognize their right to wait for international court decisions.

Article 43

\section{The reason}

Business money can only be taken abroad by the state's approval. The state has right for embargo according to the shape in the organic laws. Bosses sometimes work for political superiority, cause contumacy without a reason and also work for punishing the state by not working. Also these may an enemy state plan; so these have a strategic importance for the state as also are important for future planning health of the state.

It is an obligation, that the state shall record all the money movements of the people. The state shall use electronic money to realize this. No other material can be used instead of money. Chattel and real estate are included to the recording.

Article 44

\section{The reason}

If this is applied worldwide, people will look for usual works to earn money.

Single value reference is gold as the reference for business properties. Money and property are evaluated over gold. Work potential of gold is determined by required periods by the Kings Council of the United Nations being the main aim is single cost even for a long time and any multitude property.

Article 45

\section{The reason}

Even if it is not an obligation, it should be determined a reference for business properties. Even if asteroid mining is possible easier than done in the world $[1,2]$, still gold probably will be rare as it will find new areas in industry.

There is no entrance examination for primary, secondary and high education. Every person has to only register in their own colonies but the special conditions determined by the organic laws. Any body can register for any science section, and the special conditions are determined by the organic laws. The state shows respect for the examination system of private or state schools which are for idealist students, that they look for student as dependent of the basis of voluntariness.

Article 46

\section{The reason}

Quality will be distributed for any place. Student will not be in need in the point of culture or other needs.

As people have right on informed people to learn, also you cannot demand money, and cannot make and examination as a state, for example even if they cannot find work after university. Maybe there can be an examination after the registering, for separate students according to their quality to provide work health. Maybe even we can elect them. Nobody has to become engineer or doctor. We do not have the right to teach anything to anybody. First of all, information has an honor. You cannot use an university student or doctor as worker. It means, you played with your own honor, and made them busy needless manner. Instead of it, you must search the ways to reclaim them in a required place by a required work even by specific schools. Secondly, teaching to everybody everything is dangerous. They cannot learn how a bomb is made or how does a reaction occur. If it is required, even it can continue esoteric after a point.

Already you cannot find job for each student as there is no perfect satisfying work potential in your country even if you think, that any student has the same quality; therefore this is a gamble, and you are stalling off and making busy them needless manner; but the families are waiting for you and thus actually for statesmen along many years. Think about this.

It is an obligation, that the state shall provide free health service. The people have special problems have to be protected whatever the cost.

Article 47

\section{The reason}

Providing of health service free manner is required by the philosophy of to be state. The people do not have to collect donations. Otherwise it will be a serious morality and ethics problem.

The state recognizes extradition as debt without agreement if it is required. The state shows respect about foreign laws to be judged of its own people who live or visit abroad.

Article 48

\section{The reason}

If there is a phenomenon like human rights when we leave relative decisions, then it means any state constitution is fair enough since many people accepted it; so it can be said, that crime is universal, and criminals cannot be protected or supported. States must establish some institutions which are only interested in this subjects.

It is an obligation, that the state shall use programmable citizenship card to record any action of the people. As there shall be citizenship number, name, surname, birth date and place on the card; also there 
will exist blood group, marriage status, and partner's name, surname and birth date.

Article 49

\section{The reason}

This will be pretty protector of social order as a requirement of social order of states as it will block illegal works.

The state recognizes social forcing as abuse except the basic requirements of religion in religious colonies or secular colonies.

Article 50

\section{The reason}

Main aim is always main aim. Nobody can force someone about religion, that the things which are not the main aims in religion are two times impossible.

As the forcing about the main aim by the state, for example secular people should live in a separate colony all together. The state will not make any sanction about them but religious colonies. Also voluntarinessis is basis about this subject. If you feel ready for education about religion for the rest of your life, you should live in religious colonies by required sanctions. We must show respect for the both.

It is an obligation that the state shall protect and improve nature with its all elements. Street animal cannot be killed. They cannot disturb the people, and the state has to build shelter for them. The organic laws shall determine the personal shelter standards against the people who wish to own animal to protect animal rights.

Article 51

\section{The reason}

The state is a state with its all elements; so nature must be protected and improved. As animals, they have a right on us. As we cannot kill them, also we must pay attention about them.

There is no charge for public transport, motorway, roads, bridge, toilet and parking building beside the other elements determined in the organic laws. Also no tax for vehicles. Petroleum is forbidden but the special conditions determined in the organic laws. Any institution shall work on electricity as any machine shall use electricity.

Article 52

\section{The reason}

Even the money would not be given by the Kings Council, states have to provide them free manner by required transformations; but already to realize them, the Kings Council shall give many grants.

As it was said $[1,2]$ it is very easy to produce electricity without any external resources, free and forever by many different methods.

State of emergency, martial law, mobilization and compulsory war conditions are determined by the organic laws.

Article 53

\section{The reason}

As states may have some special conditions like in this article, the lines must be determined exact manner; because it has a vital importance to protect future of the people and the state against emerging possible big negativity.

\subsubsection{The right and the responsibilities of the king}

The king is responsible about legislative, government and justice. The king cannot alter the constitution alone.

Article 54

\section{The reason}

The king must has the highest authority as he is the most trusted person of the state, and is the representative of holiness; but he can only make change when vote majority is provided as a requirement of consultation decency as nobody is perfect.

The king is one king of any place owned in the universe. The state is the king's property. The king has right of economy on the state for his dynasty members and his citizens. This right cannot be transferred.

Article 55

\section{The reason}

Space settlements will be real soon. There will be some managements as well; so the king has to be single king of anywhere owned. To be property of the king of the state is not a gift. It is only a strategic decision as it is actually still the property of the people. The people can change any authority when they wish.

Family of the king will have many enemies in the state or international; so the king should take some precautions when it is required. No state can be exploited by a king. Know that, the king will not pay for all family members as well.

Kingdom is transferred from father to elder son. If a son does not exist, then the people shall elect the king from the family members. The king can only be changed when the vote majority of a referendum is provided. Life, property, business and chastity security of the old king except treason have to be provided. The king who fallen in a high treason has no living right; but life, property, business and chastity security of his family have to be provided.

Article 56

\section{The reason}

It is a natural result, that kingdom is transferred from father to elder son as the state is actually a team game. The state is it that even it can manage with a child. Nobody can underestimate the child king. He is the state's honor. Estimating people are always insufficient.

The penalty has to belong to its owner; so the king's family members are always protected. Otherwise, the people play with their own honors.

The king can become king in any age if his mental, spiritual and sex conditions are certain. Female cannot be king because of her creation. If the king has an accessory which renders him as unrecognizable, then by some periods which are determined by the organic laws, complete vote of his family and the Consultation Council are required as an obligation. 


\section{The reason}

The people who have some physiological problems cannot work as healthy people as well as a requirement of work health and people security. Also female easily may be impatient, weak and arrogant because of her nature. She was not created to be president of a state.

The king is the highest judgment position. He does not have to come to judgment. He can call judge and the people to his place. Nobody can take place higher than the king during judgment. The king can judge standing anywhere and anytime in the people.

Article 58

\section{The reason}

To be the highest judgment position of the king does not mean he cannot be judged. This is a right which is given to the people's honor as the king is the most trusted person in the state as actually it is required because of some security reasons. Also the king is the highest protocol as a judge. He can judge any judge as well like medical doctors are responsible and are justiciable about their treatments. Also the constitution accepts the vote majority of the people as a final decision as it was said.

The king should have more playground. For faster works, the king should do law court standing in the people.

The king is also the leader of the Consultation Council and is the prime minister of the state. He can reject the Consultation Council decision only two times, then the decision is determined by referendum.

Article 59

\section{The reason}

The king must know anything about state. He must have good intelligence because of security and work health of the state works.

As he is not a perfect person and has no absolute authority, he can only reject decisions two times.

Already there are a few prime ministers according to the constitution; so he can be counted as the actual head.

Hiding an official secret and working on works are not required by state task of special or state institutions and the people are an act of war for the king without any other reason.

Article 60

\section{The reason}

If there is a phenomenon like security, this will be provided by some people absolutely anywise, and the king is the most trusted person of the state. Nobody can hide official secret from the king. Otherwise, the king can count you as an enemy.

Granting and removing citizenship, exile, death penalty, dismiss or place change for any state task, imprisonment forgiveness are only binding with the king's confirmation as the king has these rights alone. The king has indefinite imprisonment right alone without asking. The king evaluates imprisonment forgiveness request of national or international high reputable people or any state. These authorities cannot be transferred.

\section{The reason}

Because of the above stated reason, some important moves can only be binding by the king's confirmation. Indefinite imprisonment right completely aims discipline. He can't keep people forever if they do not deserve it. Already as there is no move which cannot be done court, also the state shows respect for international courts.

Judge, governors or the Consultation Council members are only officers. The state waits for their information about their subjects.

The king has to fulfill religious responsibilities.

Article 62

\section{The reason}

The king certainly has to be the best in the point of information, morality and so religion as he has a representation situation.

The king cannot make war decision alone but compulsory war conditions. Vote majority of the Consultation Council is required for war decisions.

Article 63

\section{The reason}

The king's war decision does not mean it is right as it does not give victory warranty even for the king. A wrong decision may take the state to destruction. A serious decision like this is important to make a decision alone.

Governor and regional presidents can only be assigned by the king. If the king wishes, he can assign from out of the Kingdom Academy. There is no limit for the king to assign in the point of age, tenure of office, sex or education.

Article 64

\section{The reason}

The king should be able to assign talented people he trusts as he is the most trusted person of the state certainly.

The king elects the members of the Consultation Council without promise. There is no limit for the king to assign or dismiss in the point of age, tenure of office, sex or education. To establish sub-ministry or assign ministers of the Seniors Committee is only binding by the king's confirmation.

Article 65

\section{The reason}

The king should choose the people without promise. It means as you will not say no for lifting a stone which may cause a people on a road, also you should continue with us as you have no other work. Certainly, they will have required rights and responsibilities according to their missions; but you will run autonomous and thus the responsibility of what you do belongs to you.

\subsubsection{The rights and the responsibilities of the people}

Vote majority is binding for any voting, formal referendum is included as well. 
Article 66

\section{The reason}

If you want to make a decision together, then there shall emerge three main conditions as agreement, disagreement and a war as a result of a disagreement; so as these are valid for any majority, vote majority must be binding when vote majority of the elements is provided as the fairest manner.

Testimony is an obligation as it is a state responsibility. The people have right about demanding to be hided of their identifications as a secret witness.

Article 67

\section{The reason}

Testimony is not scary thing as it is an honorable act. Nobody can act unconcerned as they maybe will be in need in future.

Business owners can only demand money from the tax, when they have no active workplace.

Article 68

\section{The reason}

Certainly when the people have no income, the state will pay for them until they establish new companies.

Any foreign language, accent or literary language can be used for talking, writing, worship, learning or teaching except formal works and social relations if it is not forbidden because of some reasons determined in the organic laws.

Article 69

\section{The reason}

As states are social establishments, certainly for health of the social relations anyone has to talk in formal language as one common formal language is an obligation because of this reason. Otherwise, any language can be used.

Right to vote and to be elected of the people directly are only valid to send council members to colony councils. Voting of the people for election, to be elected or to dismiss can be done any time and at any frequency.

Article 70

\section{The reason}

Presidents of state and colonies are educated at the Kingdom Academy, and probably are professional genius people. They can work forever if there is no dismiss or retirement if it is required; so they will be very experienced about their people, business and settlement by having a good environment. This is very important.

As voting and the votes which are to be elected, the state will share its responsibilities by this way.

Dividing decision to leave the territory of the country is only possible as the result of the referendum. Officially declared decision to leave is an act of war for the both side and supporter states are included as well. Goods can be captured by the both sides in this case as captives can be taken for required sanction as well. For the other type of rebellions, dead rebels' property belongs to their inheritors. It is a high treason to take living rebels, living rebels' and dead rebels' inheritors as captives or touching their properties.

Article 71

\section{The reason}

Holiness of states and laws is because of human. The main aim is make people rest in peace. If major piece of the people wish to leave, a constitution shall not be binding whatever the laws. At this situation as a final act, a war can be break out as a right for the both sides.

Some small internal rebellions cannot be counted as war; so application for properties and the rebellions are different than a war. A rebellion cannot be counted as war; because state already must be had taken any required precaution; so as state can easily suppress a rebellion, this is a right of people instead of beneficence. It cannot be counted as sacrifice.

Building to do own business, transferring, selling or hiring of stores are not allowed. Stores can only be given free manner to the people engaged in manufacturing. If it is required a draw is done, and also they can be taken back for the others. The people engaged in manufacturing have right of demanding store, bazaar and business center from the state. Stores which do not require production are provided by presidential institutions of the settlements as an obligation. Doctors and lawyers have rooms in the state institutions. Lawyers cannot demand consultation fee.

Article 72

\section{The reason}

To block unjust earnings and inflation, and for production encouragement, stores cannot be included in business. The state will be giving them free for the people engaged in manufacturing.

Lawyers are wise people in people; so the people have a right on their information for consultation besides their service. This is not ethic. This is not the same thing with doctors' medical examination.

Shelters are included business; but the state determines the cost and the place, and the obligatory shelter costs are fixed for any long time. Private property to shelter or foundation property can be obtained without joint limitation. Foundation properties cannot be registered in the name of persons even the name is a person name.

Article 73

\section{The reason}

These properties can be sold or bought unlimited times and in unlimited number; but the cost is determined by the state as fixed to block unjust earnings and inflation.

Privacy of private, institutional or foundation property is basis. In these properties, garden border line; if there is no garden, inside of apartment are security border line, and it creates self-defense right by the shape determined in the organic laws. The people can shot to kill without asking strange people at anyplace in house.

Article 74

\section{The reason}

Nobody has to take special force training. Criminals are cheeky more than enough as they think their peace after the work; so the people can shot them anywise. 
Locals have right of to ask the people in local limits identify and to learn their work there. Suspected person has to gain confidence but verbal or physical abuse and insult. Local neighbors have to help if it is required.

Article 75

\section{The reason}

The responsibilities emerge in line of social state for security of neighbors and to discipline of the people with emerging national responsibility and sincerity feels as a result of requirement of holiness of social state, unity and integrity mentalities being own family is first like in this article are an obligation against destruction of the nation.

Officers on secret duty have to make a connection with locals before operations to protect work health against innocent or criminal people. Citizen who is waited for help has right of to call the officers' institution by the state's official phone numbers which are generally formed by three numbers.

Actually some patrol guards from the guards' local, would be enough to ask identity. They use vehicle and can ask people and talk like "I can take you there."

Fee is return of a labor. A business agreement is an obligation whatever the required total work time. Employers have to inform worker's constitutional rights, and have to be had been determined the fee. If it is not against the organic laws or constitution, employers have to pay the fee of the worker when the worker left the work. Any work part is counted as completed when the worker left.

Article 76

\section{The reason}

People certainly have right of to ask about salary. They do not have to listen life experiences. Business is a serious joint, and workers are very important as they are very prestigious even employers are more prestigious than the workers.

Employer will be able to see the work history of the worker by the citizenship card; so if the worker works on abuse instead of doing work by leaving any work as in-completed for the full salary stated in this article, employer can go to a law court or can check the worker before hiring.

Courts can reject the agreements which are not in an accordance with the constitution, human rights, international laws and the organic laws, even if the agreement was read or not. The people are not responsible about taken insufficient precautions which are done willingly or not and include abuse. The damage suffered by the people belongs to that person or institution.

Article 77

\section{The reason}

Abuse is a serious state issue; because holiness of states is because of defending people as the state has no other work.

Any citizen has right of to be judged free and fair manner. When the decision is not liked, the people have two more application rights for the same lawsuit in the same settlement. Every time, different judge shall investigate the lawsuit as judge can reject with a reason without doing court if it is read. Formal judgment is binding and nobody can be taken to another court, institution and person that the people are not responsible about them.

Article 78

\section{The reason}

For perfectness of justice works and to get rid of the responsibility of the state, it is the best precaution.

Abuse, working on absurd and abuse of office are crime whatever the person and the institution. If it will not bring some results out, criticizing of any element and act in the state is crime which has a shape like in the organic laws. Judgment and referendum results are binding about this subject.

Article 79

\section{The reason}

We must show respect for the decisions result of a consultation. It is worry, that when consultation results are not perfect, the other group or person may be more well-directed. This has no meaning but an experience about the subject and the other group or the person. Everybody needs time if it is not a high treason includes crime. Instead of to stay in claim position, then both sides will be in proving position.

Carrying firearm which has certain standards determined by the organic laws is allowed in order to defend. There is only carrying license, and it can be limited by the organic laws when required. Firearms cannot be used for fun. It requires imprisonment without fine. Limited license owners have to get an electronic composite protection for the gun, otherwise the state shall take the license.

Article 80

\section{The reason}

Carrying firearm in order to defend is a natural human right; so people should have firearms whatever the result. This right is limited for some people. They can only carry gun when they go out from their settlements by informing the neighborhood chief. For the negativity, death penalties are included like this crimes.

Citizens who stayed at foreign countries more than the determined time in the organic laws shall be denationalized. Spending time in foreign countries can be removed by the rule determined in the organic laws by sending time in the mother land.

Article 81

\section{The reason}

States spend their all time, money and labor to protect their states, culture and to discipline the people. This work certainly will cause jealousy. We must show respect for states about this subject.

In the other hand, people will lose their own culture and creation in a foreign state; so also by this way, we can protect ourselves.

It is an obligation, that majority of the apartment shall visit the new neighbor with some gifts at the same time in the neighbor's house, the apartment's garden or in a meeting salon. This work is under the control of 
the neighborhood chief carries firearm. Also neighborhood chief is responsible about private buildings in the point of meeting.

Article 82

\section{The reason}

To block extramarital relations, illegal works and also to provide information for the state, the people always have to know each other as a requirement of to be social state.

Privacy of communication is basis but the special conditions determined by the organic laws.

Article 83

\section{The reason}

The people certainly have right of to demand protection of their personal information, communication is included as well.

Moving to foreign states or moving in the state, and travelling to foreign states or travelling in the state are the rights protected by the constitution but the special conditions determined by the organic laws.

Article 84

\section{The reason}

To be on creation, as stated the above, even if some rights are limited, this right must be provided by the state.

The liberty of religion, conscience, idea, opinion, expressing and disseminating of idea are protected by the constitution being the shape is determined in the organic laws.

Article 85

\section{The reason}

Some actions as a result of basic requirements of being human have to be allowed as they have to be on a certain line because of the polarized nature of existence.

Privacy of private life is basis but the special conditions determined by the organic laws. Private, personal or formal press elements cannot publish any information about people if the people do not allow as press has right of to prosecute, and press cannot take photo or record video before asking. Otherwise it shall be abuse of office.

Article 86

\section{The reason}

As it is a basic human right, also its protection must be a basis. We must take required precautions against extremist who may behave like social responsibility drunk by a drop. If press says they were disconcerting when a move against this article by press emerged, and if they could not bring an exact evidence out, an excuse will not be enough since the state uses other official institutions for this.

They can easily present people wrong manner. Even this situation may cause death of that people. This is not about providing intelligence or enlightening people. They must wait law court orders about any subject.

The people can demand information or write formal petition about state works or the other works which are determined in the organic laws. Private information of the people cannot be given whatever the reason.
Article 87

\section{The reason}

The state is the property of public at last; so the people have right of to learn about the state work or the works related with them.

It is an obligation, that foreigners shall give extra tax. There is an exemption for this extra tax if the people satisfy the conditions in the organic laws. Visitors or permanent foreigners have the rights and the responsibilities of the constitution.

Article 88

\section{The reason}

As stated the above, states send their all labor to protect and to improve their states. This is the most serious work; so to be deterrent, states must demand extra taxes from foreigners.

Marriage is right for female and male as divorce is right for female and male as well. Age limit is 16 for female and male. Making children is right protected by the constitution as it is encouraged by the state. There is no number limit if an opposite condition is not determined by the organic laws. Male can marry more than one female according to the organic laws. As male and female can have a separate house when they reached 16 , also when they married, male and his wife can have separate houses.

Article 89

\section{The reason}

Female is life friend for male as male is for female as well. Both of them in need for each other; so even if they have different responsibilities because of their different natures, marriage and divorce are rights for both of them.

Families teach nothing from 16 to 18 about marriage as already there is nothing to teach. Human is not an artificial intelligence. Most of the things about life experiences are natural humanistic instincts. Already they do not do sex or experience love with their brains.

Torturing and acts which are not in accordance with human honor are forbidden for any formal or informal works.

Article 90

\section{The reason}

Torturing is not a part of justice. It is completely personal. Anybody has to live on a line according to laws.

Resignation is preserved right.

Article 91

\section{The reason}

Nobody can be forced to work forever. Also otherwise it will not be healthy so much.

As making art and doing science are protected by the constitution, the state encourages for them, and takes required precautions as well.

Article 92 


\section{The reason}

Science and art love are always together with human as a requirement of human creation. Even human grows alone, it will emerge by itself. Also they have many benefits to improve of civilization; so the state has to take required precautions and has to encourage.

Extreme dresses and body modifications which are not in accordance with the general opinion of the people are not allowed.

Article 93

\section{The reason}

When requirement of to be social state and philosophy of to be state warned, states which are service and discipline establishments have to take required precautions to walk on a right line of their people, and to protect family and public.

No decision can be made against the constitution for formal or informal works. The people are responsible as well together with managers about application of the constitution.

Article 94

\section{The reason}

As the constitution is the sum of the main laws which provide healthy walk on a line, nobody can make a decision against it certainly. As a requirement of social state order, the people also will be responsible about it beside managers.

Meeting and demonstrations are allowed within the framework of the organic laws. Demonstrations cannot be done without asking besides allowed places.

Article 95

\section{The reason}

As human is a social existence, also they can realize some shows about some subjects which are determined by them within the framework of some laws certainly like everything. Everybody must show respect about it.

Right to make news by media is preserved besides the special conditions in the organic laws. Press confirms, that they shall show respect for privacy of private life, holiness of justice, personal rights and freedoms.

Article 96

\section{The reason}

Press is very strategic for enlightenment of people; to protection, improving and spreading of information; business of people for fun and learning, and providing intelligence for the state.

The people have right of to establish society to be social, and have right of to establish trade union to defend their rights and to improve themselves about business. Workers have right of to strike as employers have right of lockout within the framework of the organic laws.

Article 97
In the name of to be social state, the people must be able to establish some unions and societies. It is a serious requirement for improving and protecting of personal relations and culture.

Workers should take help about their works by the way of establishing some unions.

For example, if establishments cannot pay, they have no other choice than lockout. They cannot do lockout without any reason given.

\subsubsection{The rights and the responsibilities of the dynasty}

The dynasty is honor of citizens. Any person and institution are responsible about their life, property, work and chastity security. Damaging them willingly is high treason.

Article 98

\section{The reason}

As the king is the most honorable person in the state, certainly his family is the most honorable family in the state. These rights are the rights of the king on the people.

\subsubsection{The rights and the responsibilities of the state man- agers}

Any people who have order and obedience law among themselves are responsible about their life, property, work and chastity security.

Article 99

\section{The reason}

If an unlovable situation emerges in work place, anybody will be responsible about it.

Keeping a daily is an obligation for any manager in private and state institutions the king is included as well. An electronic copy is also obligation. Even if diary is a summary, they should give place to details as much as possible personal relations are included as well. If diary owners did not notice an opposite condition, the diaries' privacy is basis.

Article 100

\section{The reason}

This is required for intelligence about losing, death or threatening. Also it will help improving social order by scientific analyzing.

Seniors Committee has right of to have personal armored air vehicle, armored land vehicle provides the fastest and the most security transportation and expert close bodyguard. The state has to provide these possibilities. The state shall build shelters for them in all of the colonies according to the standards determined by the state.

Article 101

\section{The reason}

As they are the busiest and the most authorized people of the state, Seniors Committee has to be protected, and the state has to provide some possibilities for work speed and health.

\section{The reason}


The Seniors Committee has right of to judge in their areas when it is required. They can judge standing. Each one has to obtain one helper as judge.

Article 102

\section{The reason}

The people who are in this expertise should be able to judge for work health and speed.

Vote majority of the Consultation Council is required to make changing in the constitution.

Article 103

\section{The reason}

We cannot make referendum continuously. It causes time and money loss. Already it is not appropriate in the point of method; because doctor does not do consultation with the patient about every subject. Already anybody will know the subject, and reject it by a referandum.

It is an obligation, that state managers shall obtain helper to make consultation.

Article 104

\section{The reason}

It is especially required by the people who are inclined to wear down and mistakes. They always must obtain helpers who show them their mistakes, suggest and watch their back against complexity and difficulty of state works. Powerful people always have the best helpers. Also this is required by the new people will take place instead of them or as new leaders' helpers.

The state waits for solution of the state problems from its managers according to their duty even if there is no complaint. The managers are responsible about accumulated problems.

Article 105

\section{The reason}

Sometimes it does not matter for people, that is it good or bad. It does not mean it is right. To be interested in the state problem when a complaint is made is not in accordance with disciplining of the state.

Judge cannot be suppressed and disturbed. Going and result of lawsuits are under the control of judge. Judge has right of to be mediator if both sides of plaintiff and defendant are willing.

Article 106

\section{The reason}

Judge who protects prestige of justice and is waited for this, certainly determines result and going of lawsuits alone.

Governors have right of to judge standing in the people at anywhere. It is an obligation that each governor shall obtain 1 helper as judge.

Article 107

\section{The reason}

For work speed and in the name of to block hatred, governors also should be able to judge standing like the king.
There is no work time limit for state managers even if retirement time was completed besides the special conditions determined in the organic laws.

Article 108

\section{The reason}

Constant changing is not efficient. Changing the people who have different tactics, strategy and idea is a time loss. Some consultations must be done instead of this. Nobody has an absolute authority. If it is required, anybody can be changed.

The king has right of changing any manager even managers were elected by the people before or he can reject the vote decisions of the people for parliamentary works.

Article 109

\section{The reason}

The state is free to realize works which are thought as more efficient strategically by the state.

The head of the Noble Council is National Justice Minister. The Noble Council can use the Seniors Committee to make consultation as helper for its lawsuits as it has different position.

Article 110

\section{The reason}

The managers like these ones as the most experienced managers should take their helps for their own works.

\subsubsection{The rights and the responsibilities of the institutions}

Law courts are independent as they cannot be suppressed. They always open for the people without cost. They cannot stay away from dealing with cases. The people have another religion have their own autonomous courts against possible conflict between laws, and they can make any required decision death is included as well if it is not against human rights, their own religion or the constitution. The conditions are as the same as in the organic laws.

Article 111

\section{The reason}

As it will be a right claim to work for affecting, threatening or suppressing the court, also it is a great disrespect for justice and judges who are protectors and representatives of justice as a big crime.

It is an obligation, that the Noble Council shall develop administrative courts. All justice works shall be broken into small pieces by categorizing for the main ministries, that the state institutions are dependent of them.

Article 112

\section{The reason}

For scientific diagnosis of emerging problems about health, national security, family, army and social relation; for re-editing and improving of the organic laws for tomorrow's justice men; for providing state support by high experience 
and for learning of institutional mechanisms separately, judge should work as organic even if still they can deal with any type of case.

It is an obligation, that Head of Religious Affairs shall question and provide the health of religious information. There is no difference between any elements of the state for Head of Religious Affairs about this subject. Not about to be believer of wrong information but it shall make required sanction for the people who insist about spreading of wrong information.

Article 113

\section{The reason}

As religion is the most sensitive thing for people, against possible emergence of unrest, the state has to take required precautions about religion as a requirement of philosophy of to be state.

The Consultation Council does not recognize the people who are not citizen as its member. The Consultation Council is responsible about legislative, government and justice.

Article 114

\section{The reason}

Certainly, state works are done by citizens; so the Consultation Council cannot accept foreign people.

Organic and constitutional rights and responsibilities have to be hanged on a place where anybody can see it there in any institution. It is an obligation, that institutions shall do practice about these laws by some periods determined in the organic laws, and they have to be sure about their memorized. It is an obligation, that institutions shall notice about the practice before. Putting out a feeler is a crime.

Article 115

\section{The reason}

As any person is in a learning process, and as the state is the head teacher, also the state has to teach about laws. Otherwise the people shall not be responsible about their acts includes crime.

Duty of the Colony Council is as protecting the condition of the colony, also improving the settlement by strategical and social projects.

Article 116

\section{The reason}

It is the most efficient way technically, that selfmanagement is limited by settlements. The people can count their settlements as state and can feel as they manage their own states. The managers who are always together with the people will be more efficient, reassuring and enlightening.

Settlement Council members must search ways to improve the settlement for any subject by the grant given by the Kings Council. They can invite people to their settlements. Any people can think like "How can I spend my infinite money by doing business?"
The Consultation Council has to keep National Education Minister, National Justice Minister, National Economy Minister, National Religion Minister and regional governors as the principal members. These are the elements which create the Seniors Committee as they are the most authorized people after the king. They have no superiority to each other.

Article 117

\section{The reason}

As a requirement of hierarchical order, it is the most suitable, that there must exist the people have different expertise areas on the head of the basic strategic elements.

The Kingdom Academy looks for student in any area by intelligence test being social sciences and genius people are prior. There is no limitation for the student number. The Academy can start to teach from Kingdom Primary School. It is a homeland duty, that anybody has to look for student for the Kingdom Academy. Governors and presidents of regions are from the Kingdom Academy. The Kingdom Academy is the single formal science authority for the state, and is autonomous.

Article 118

\section{The reason}

State works are serious works which require expertise, and success is cut out for geniuses. They will remove the break when the others cannot think to do it.

Science works must be autonomous. They must have any possibilities as independent of industry especially in this article's state order. They should not do business. When they decide a subject international by dividing missions for example for space, they should be able to do what they want, whatever the cost. They should have great potentials like states. Especially doctors must be able to take any amount of money. They must create this potential. Universities must have any possibilities.

Interest areas of the Noble Council are special cases about internal threats, external threats and international relations which risk prestige and unity of the state. The head can decide the case provides the condition or not alone.

Article 119

\section{The reason}

The Noble Council is an institution, that any justice institution is connected to it; but it has a special strategic condition as a requirement of hierarchical order naturally.

\section{The Constitution of Nations}

\subsection{General shape of the Constitution of Nations}

The highest council international is the Kings Council of the United Nations. All of the states exist accept the Kings Council as single binding authority for any subject international.

Article 1

\section{The reason}

People, statesmen are included as well always look for an international authority, that international strategical subjects 
are discussed and resolved there. This authority should be the Kings Council.

If it required, the Constitution of Nations recognizes vote majority of referendum as binding and the final decision for any subject but some special conditions.

Article 2

\section{The reason}

As it was said the above, to be fair and escape responsibilities, it is the most suitable attitude always.

The Kings Council is managed by co-presidents of National Economy Minister, National Justice Minister, National Religion Minister and National Security Minister of the sates who always stay at the foreign country has the Kings Council as an obligation. Foreign language is not an obligation. Vote majority is basis in the Kings Council. The Kings Council elects its own head. The head is not the highest authority in the world, that is only responsible about sessions and representation. The decisions are only binding by the vote majority of confirmations of the kings. Kings can only reject the decisions of the Kings Council only two times, and then referendum is made but special conditions.

Article 3

\section{The reason}

As the Kings Council discussed any international subject, also they must be formed by co-presidents as kings' representatives.

The basis is voluntariness for the Constitution of $\mathrm{Na}-$ tions; but if it is required, the Constitution of Nations waits for sacrifice, is able to make required sanction. The Constitution of Nations aims absolute world union by these conditions. The Constitution of Nations does not recognize any international or national strategical unions and commercial agreements besides religious or cultural ones. All of the productions are common property of the world. The Kings Council can discuss business potential of states.

Article 4

\section{The reason}

Justice cannot be provided without sacrifice; so all of the nations must show sacrifice.

Work potential of states may be used for only one foreign country as an abuse; so the Constitution of Nations does not accept strategic unions and commercial agreements. Everybody must sell the properties to anybody, and states must already be ready being had been taken required precautions by some ads and offers by the grant.

I am not prejudiced about strategical unions for the current position; but they cannot create miracles. The same effects can be reached by bilateral relations. Even the unions can hide actual inaptitude of people and statesmen while they give hope about good things will be. Additionally a boring bureaucratic process will naturally occur. If the same effects can be obtained, we must leave the one which makes us busy and probably hides abilities. Each state should stay alone. If they want an union but financial one, still they can realize it by some social projects continue forever by some periods.
The Constitution of Nations recognizes civil service as international duty, and charge some responsibilities about the Constitution of Nations. Officers' salary is paid by the Kings Council for any state as fixed for any state.

Article 5

\section{The reason}

As this is actually a transformation, it is not different than paying of a state.

The Constitution of Nations supports sovereignty of the people have own race and language in the world. Looks for sample land and makes required consultations with its real owners to realize this mission. Also it gives the share of these people from space colonies by the determined standards in the organic laws. If it requires, the Kings Council shall open new lands by filling sea or ocean.

Article 6

\section{The reason}

As required by one world order, any nation must have its own sovereignty to realize the main aim for living free manner.

\subsection{The rights and the responsibilities of the Constitution of Nations}

\subsubsection{Religious rights and responsibilities}

The Kings Council protects religious freedom, and if required, it shall make required sanctions. The Constitution of Nations recognizes vote majority of religious leaders and formal ministries for religious disagreements as binding. It does not recognize religions include unlawful orders.

Article 7

\section{The reason}

Certainly administrative authorities and administrative people have holiness because of defending human rights, have to take required precautions about like this subjects have potential to run people into unrest.

The Kings Council recognizes prophet, leader or representative of religions as universal values. They cannot be reconciled with a race as it shall be racism.

Article 8

\section{The reason}

Prophets absolutely must appear in a nation as there is no alternative. Even a few prophets live at the same time, one of them will be leader and manage the world in the name of God, as anybody, any order and anything are God's own property. It does not mean that prophet is that nation's own value. Holy books are for anybody. Anybody or any state can adopt and discuss about them. Some prophets which are sent to some nations have the same potential even if they are not universal. The message is always universal even if God does not wish to call international.

The Constitution of Nations does not recognize to make war by army for the sake of religion. Working for notification for the sake of religion is limited as well and states' own formal religion is basis about this 
subject. The Constitution of Nations only allows activity of the people who have a different religion than the formal religion of that state to protect of them themselves.

Article 9

\section{The reason}

As it was said [2], God did not create us for his revenge. $\mathrm{He}$ has no other choice. The main aim is to know of and to listen of God. It can be done anywise in our age.

The Constitution of Nations does not recognize to make war for expansionism. It is an obligation, that any nation shall add an article about this subject to their law constitutions or shall give an undertaking in writing.

Article 10

\section{The reason}

As it was said the above, we can produce any raw material by one-time cost anywise. Also as we do not have any other reason, we do not need expansionism. All the world can live in a city in theory. We can do what we will do in our land, that even we cannot give its right completely.

\subsubsection{The rights and the responsibilities about wars}

The Kings Council does not feel as responsible to make war against them and is not interested in their results but human rights are violated, that civil war which is because of dividing decision to leave the territory of country by referendum, civil war in a country or a war between two countries which are because of a joining decision to another country as the result of referendum.

Article 11

\section{The reason}

As the main aim is sustaining life, the Constitution of $\mathrm{Na}$ tions should show respect for choices of people.

The Constitution of Nations recognizes entered place to make war as homeland for the attacker without looking at result of war. Sacking, damaging public property, rape; taking as captive of women, children and senior citizens beyond forcing them not to be in need of them, and freeing prisoners are forbidden, and are high treason. It does not accept colonialism by forcing. Contracted loyalty standards are determined by the Kings Council and the Constitution of Nations.

Article 12

\section{The reason}

We must follow these rules to prevent war crimes and manifesting of justice. Nobody can rape homelands and human rights as they cannot block the basic human rights.

\subsubsection{The legal rights and the responsibilities}

The Constitution of Nations protects the laws and the international agreements which are not included in the Constitution of Nations.

Article 13

\section{The reason}

The Kings Council which is the single binding authority international certainly must protect the other international organic laws and agreements as it discusses them.

The Constitution of Nations shows respect for migration conditions of states.

Article 14

\section{The reason}

The Constitution of Nations must show respect for the labors spent to protect state and to improve people.

There is no institutional or personal action which cannot be done law court.

Article 15

\section{The reason}

As also stated the above, in the name of to be clear, to escape responsibilities and as the people are not perfect, not to be of the people or the institution which cannot be done law court is always the best attitude.

No decision is binding unless secret or public reason was declared. Secret reasons cannot be hided indefinitely.

Article 16

\section{The reason}

Certainly any action has to have a fulcrum. No decision can be made, that it cannot be categorized.

People are responsible about laws of crime or right of the states where they exist without any reason given, if an opposite special condition is not determined by the organic laws.

Article 17

\section{The reason}

People should know, that they do not have to visit or immigrate to other states. They must show respect about the other states' laws, and they must behave according to these laws.

The Constitution of Nations does not recognize embargo. Embargo is only possible with the Kings Council's confirmation to discipline.

Article 18

\section{The reason}

The Kings Council makes the final decision between states for the disagreements which cause wars; because one world order requires this.

The Kings Council divides fair manner predisposed places in space to live as space colony according to its own standards. It does not recognize the agreements done before between persons, institutions or states to share.

Article 19

The reason 
As states are in infinite need, the Kings Council must take required precautions against possible emerging negativenesses for space as well.

The Kings Council shall evaluate rejected imprisonment forgiveness request of national or international high reputable people or any state.

Article 20

\section{The reason}

Some people who can be counted as a president and have many labors spent for civilization should have a right like this.

\subsubsection{The civil rights and the responsibilities}

The Constitution of Nations recognizes as crime to produce nuclear bomb whatever the size. The Constitution of Nations only allows to be produced of them to use for industrial use if it is authorized by the Kings Council. Fission reactions are forbidden even for energy producing; but fusion reaction can be used for energy producing or other industrial heavy works according to the standards determined by the Kings Council.

Article 21

\section{The reason}

Fission is a radioactive deadly reaction. It is used for generating energy and manufacturing bomb; but it can damage people and environment, that its repair almost impossible. An accident is accident as it is not done willingly, and is unpredictable. It does not mean anything when it emerges. Fusion reaction is safer than fission even it can produce radioactive waste according to working principle.

As producing bomb, it must be completely limited for nuclear weapons. People can easily exit from humanity even for smaller subjects, that if the subject is their lands which are the result of many years' labor, they can easily lose pity feelings. This is never acceptable; because people have no other work. At least they will work anywise. As this is not acceptable certainly it does not mean it shall not be realized.

These bombs can be used for industrial use. For example we can use them for lowering density of lands while working on carrying land by digging to improve life time of machines.

Actually, we do not have to use nuclear reactions to produce energy even if it is a fusion reaction; because it is not so hard to produce energy. We can produce it as cheaper than nuclear by some methods, that they work forever without an external energy resource with or without magnets $[1,2]$. A state has 100 million people won't need energy any more by like an amount of 5 billion dollars money. Moreover this generators will be bigger as they work for heating and cooling as well in summers and winters.

Also we must only use second world war weapons for armies as a first move. If the aim is making war, it will be enough as well. Already that weapons can be manufactured fast manner by our current industrial infrastructure; so if it is needed, we can produce them. We must determine some standards according to population, and nobody should able to produce more weapon than the determined number. Also we must let UN know about them. We can send nuclear wastes and wepons to the sun by the below stated technology free manner.

It is an obligation, that any state shall create a settlement which can only be used for its building reason against natural disasters and wars according to the standards determined by the Kings Council.

Article 22

\section{The reason}

As people need each other, also nations are in need. There is no difference in theory. Our world is exposed against high devastating natural disasters from space or on itself by some almost certain periods. Also people may be forced to move because of war and epidemic diseases. If these negativenesses occur, then these precautions shall not be kindness as they are actually right of that people being the same is valid for any state as well.

The Constitution of Nations recognizes amnesty of prisoners in the state of defender as an international crime during wars for attacker.

Article 23

\section{The reason}

As stated the above, crime is universal. Amnesty of prisoners is not suitable in the point of ethics and morality whatever the reason.

The Kings Council shall determine tonnage against asteroid mining and real space mines. It is an obligation, that if someone finds a mine bigger than this tonnage, it must be notified and then infinite number of initiatives can work on it. If a notification is not made willingly, the Kings Council shall make required sanction. The finder of these mines have bigger tonnage than the determined tonnage has share right from extracted mines at the amount of the determined by the Kings Council. The Kings Council encourage units which only search for mines for the share.

Article 24

\section{The reason}

Asteroids in the sun system are pretty satisfying even in the point of rare elements in the world. The required technology to bring them to the world is still expensive; but as it was said $[1,2]$, we can obtain much more acceleration than jet fighters in the same volume without an external energy and problems like heat and air need. It can be manufactured only by one-time cost of the materials.

\section{More prestigious banking: Perfect capitalism}

I thought, that actually we can place banks into a very critical position for our future. They can help us more than enough.

\subsection{General shape of some economical orders}

If you want to establish a state management order, there is a limit for this since emerging combinations are limited as will mean the same thing as well. As long as there is an action in the name of management, it is going to be categorized spontaneously. In the same manner, if you want to determine an economical order, also it is going to be categorized spontaneously; that actually there are three possibilities such as capitalism, socialism and communism based on socialism. As long as there is an action in the name of economical order, it also is going to mean one of them even if it is a partial action in a different economical order. As these cannot be related with someone's opinion or with a state since they are pure academical information, also they have different benefits and properties. 
In capitalist systems, state feeds its people by capitals namely by employers, that state says you "You have nothing. If you want to live, you must work." They are not interested in your income amount. As socialist systems, they are not concerned with financial gain; but they give people what they deserve as a result of a labor. As communist systems, they are also not concerned with financial gain; but they give people what do they need, not everything they deserved as a result of labor.

\subsection{Money}

To realize a right analysis about these financial managements, first of all we must determine something in the name of economy, that we must start it with money.

Money is never the main aim. The main aim is creating possibility for yourself. The same work may cost $\mathrm{x}$ amount of money as also may cost $2 \mathrm{x}$ money in another day as well; so instead constantly collecting money, being made allowances against the risk of the value change in money, we should keep cash at the amount according to acceptable level risk as we should fund the rest of the money or again instead of it, it is more sensible that we should owe for funding, and should pay for the dept in the long run. Also we must find exact solutions for the things which cost constantly as soon as possible when we earned.

This value change in money can cause troubles in states by creating an imaginary effect because of the financial movements in external and internal trades. If it is required to give an example to understand it better manner, it can be handled the below stated mining facility. Assume that you have been developed this technology. The cost of this facility is 10 billion for a facility which brings 100 billion money out annually. Thereupon assume that a state wants the same facility from you, and offered 3 times cost of its actual cost for own state. As the actual aim is bringing money out for your own state from all the money of the world at the amount as high as possible, also you do not want to create a joint against you about this subject; so either you decline the request or you accept but determining some conditions. For example you say, that "I shall build; but its cost is 100 billion, and after 5 years, you will start to earn since it brings 20 billion money out for you annually." if you accept it. After that as long as you take the money as cash or by parts, you search for the ways of funding to close the gap because of the joint state about mining as you determined a poor limit for it as well. At this condition, the money of that state loses value; because even if the return of the same labor must cost the same amount of money, as you did not accept a joint, you rendered valueless the money of that state relatively to you by the limit you determined, as also you limited the actual upper limit of all the money of the world for the buyer or maybe for a third state. For the same amount of money it is like it, that your people spent less labor. If you did not build it, the money value of that state would become zero relatively to you.

If internal trade is handled, we can start it from salary hike. By the salary hikes, cost of existent all elements increases especially selling prize of houses, and this evaporates the extra taken money. Namely because of our jerk, we evaporate billions of money by consuming each other since someone needs labor of another one. Instead of salary hike, we should spend this money to find exact solutions out for the things which constantly requires money for people.

As these effects can consume us during internal trade, also can born fatal results for states especially for the states could not be inclusive of production. All labors of these states evap- orate. They have no other choice than putting signs at the entrances and at the exists of their states, that writing 'closed' on the signs. They also lose existent remaining work potential since advanced states offer high salaries and better possibilities.

By looking at these information and at this properties of money or actually of trade that the same effects exist as long as a trade potential exists even without money, to determine which one is better yet of the above stated financial managements, it can be said, that certainly state should not follow money. First of all to guarantee itself, should not be concerned with financial gain and should find exact solutions out about some needs which cost constantly at least to keep brain and work potential in hand such as electricity, drinking water, shelter, communication and transportation.

\subsection{Socialism or Communism?}

Theoretically the most powerful management is communism; because it does not recognize private company and thus controls all the money. States usually takes $1 / 5$ of the money from trade income directly besides the other ones as tax, and cannot determine what private company must do by the rest of the money; so foreign states can easily use our work potential and brains instead of us in our own countries, and then they bring more money out from all the money of the world for their own states by only giving you $1 / 5$ of the money. They can fund by the rest in their own states, and then can call you brains and work potential for high amounts of money. Actually this can be counted as a crime at the level of becoming a traitor. Communism does not allow this, and it controls all the money instead of $1 / 5$.

Even if it sounds good, practically it is able to born fatal results as well; because it requires very high condition against staying breathless. Also it requires high and wide technological infrastructure currently exists like Japan, as also requires an educational system and tradition aim educating loyal and diligent people like Japan has, that danger still cannot be counted as gone away.

Additionally, it is an important minus that people have no unlimited earning potential in communism; because the persons who are unconcerned and who always wait for labor of another person make state stayed behind, that we cannot always wait for emergence of a hero. Without doubt, in such a system which there is no worries about future, people tend to work at lower potential, that determining of real face of people is almost impossible there; therefore actually some feelings, characteristics, and properties which belong to human and should be autonomous such as victory, domination, working, reward, freedom and belonging should not be damped down.

Also by looking at these information, it can be said that giving only needs as a result of a labor will born fatal results; therefore at least like in socialism, people must take what they deserve; but even if is like in socialism as well, as there is no private property and even if people earn more money as long as they work, as it could be done according to an inappropriate reference, still it does not mean the danger has gone away. It is such that; because as there is no private property, no civil servant has absolute economy right on institutions. Each earned money of them does not belong to them. This means there is no boss. It means still there is a limit if a civil servant brings billions of money out for the state whereas if is earning like a CEO. Even the same money could belong to the civil servant in a capitalist system as well.

As a result, if it is required to make an election, socialism 
seems more secure. People will not stay in need such a system; but is better one possible?

\subsection{Perfect Capitalism}

As a result, such a system is required, that it had already been taken required precautions against any negativeness, and all the work shall continue by improving itself and shall continue oneself even if there will be insufficient statesmen and private companies. This system shall defend us against high condition requirement of communism which emerges because of insufficient statesmen and institutions since you have to work together with people in such a state like company. This system shall satisfy money earning wish of people and shall not put a limit to earn, as also shall provide the basic needs even if people have no work at that time even when they were born. Such a system is only possible by taking socialism and capitalism to a common and uncertain point. This point is a point, that while two economists are discussing, one of them says is socialism, and the other one says is capitalism; because actually you can turn a private company into a state institution on a formal paper in seconds, that it is possible still everything will be the same such as income, worker number and managers. Additionally it is possible, that in a socialist system smart and diligent managing statesmen and working public there, people can easily earn more than the people earn in an insufficient capitalist state. It is not only about methods.

Banks are the most appropriate applicants to be touchstone of such a system. Banks shall constantly take share from active business of all the world, that namely they shall become absolute joints of any company by some ratios like $1 \%$ or $0.0001 \%$. As a response, they shall find work for the people who want to work as worker or shall establish work places for the people who want to do business by preparing them for the interview of the committees of the Kings Council for the grant. Just state will determine a limit like 15 days against the application of people to another bank since these works require planning. Banks must answer the person in 15 days as an obligation, and the person cannot apply another bank during this time.

The interviews are pretty important as also the quality of banks is important; because you must convince the committee about your bringing money out. Right this point, maybe the bank will show the right condition over the above stated database system of trade when the committee did not see it.

By this way, maybe workplace owners will be offered about external trade even if they would never think that. Banks will work about ads, finding new machines and workers out for them. Maybe sometimes banks will offer zero risk external or internal trade by risking any negativeness oneself, and the workplace owner will continue from the old position even for the worst possibility. By the way, maybe the machines of the workplace owner will work 7 hours in a day instead of working 3 hours, and maybe the worker will work even in nights or even the bank will bring new machines for the work place owner together with some workers. Maybe this will be for a short time; but at the end, for example maybe the bank will present the machines, and will say the workplace owner can throw them to trash if wishes since more than enough money was earned.

Banks will realize this by economists. The economists shall always be busy about improving the workplaces which are in their responsibility areas by searching new work areas and trade potentials over the database in the name of companies. Any worker shall be able to apply for a work by coming the bank.

Banks shall not demand more than the determined share by state like $10 \%$. The workplace owners shall pay for this share from their own incomes. This amount of $10 \%$ can born new banks as well; because while one of them is demanding $2 \%$, the other one demands $10 \%$ as it works with qualified personal tried most of times. Nobody shall apply the committees without banks. It is and obligation that banks shall keep lawyers according to the company number in responsibility area. Additionally, they should keep industrial engineers; because a factory with its all elements can be counted as trade element since nobody has to work under the yoke of someone else. After taking the grant, banks suggest to the new employer to establish a factory with its all required elements. Banks can demand extra money for this service as cash or by parts. The workers of banks will earn more money as long as they do work more. By this way, also banks are going to earn more as long as they make employers earned more.

\subsection{A brief discussion on possible practical transition}

When a person from a state bought something from another state, seller state shall pay instantly for the buyer, instead of the buyer by using own money unit. After that states shall discuss the current dept status, and shall make an agreement about it. Relative limits can be determined according to gained benefits. By this way naturally, while a state has $\mathrm{x}$ amount exchange limit, another one will gain $5 x$ since it can provide more benefits as a response; but right this point, the UN must force especially advanced states for extra limits to improve the abilities of lower level states; because most of the extra limits will be for funding to feed the world by making them gained from time. Once some people visited Prophet Muhammad and said that 'Please change the costs in the market'. Muhammad said 'I wish from God abundance'. He said such; because any person manufacturers are included as well can obtain any thing cheaper if there is a rich market for any kind property. Temporary solutions are not enough. Public have to make the necessary effort, and statesmen must make required transformations and provide social organization by right solutions.

You do not have to be in another state by defeating it to improve the abilities of your own state. If you can feed them by the industry of your state, tomorrow also you will buy any required material and machine cheaper. Advanced states still will be earning more and more. By this way, also cash money will gain value even if it is not used for a long time since rich market was aimed. Money itself will be one of the best funding material by this way.

Once King Solomon wished feeding an ant. He found an ant and built a shelter for it. After that he imprisoned the ant into the shelter after putting a wheat grain inside. He forgot it. When he remembered the ant after a time which is more than the duration the ant needs to eat the wheat grain, suddenly visited the ant. He saw, that the ant had not been eaten all the wheat grain. Half of it was still there. Solomon asked to the ant "Why is such?". The ant said, that "Before you imprisoned me to feed, I had no worry about my sustenance since I knew God provides it; but when you became inclusive of my sustenance, I scared and thus kept half of it since you may forget me.". Yes maybe God is guarantor about sustenance; but managers can easily block it by being responsible about it. Right this point, you cannot complain about God for that result. You will search your right without becoming a criminal. We should think people as they live their own planets; so every person has the right to do own business or of not working. Anybody can build any size house at any place, can hunt or farm. If we involve in business of people, then it means we go under a serious business. It means a negativeness which 
its possibility is $1 / 10^{6}$ is constantly emerging somewhere. We should play onto their children. We should grow them with a global perspective together with national feelings, and bring for them working and producing consciousness out.

I said the above that any production is common property of the world; but there are some dilemmas; because a state may fall into a bad situation according to trades when some states work better as already states do not need money since they will give it; so some states may use another state's work potential by some workplaces in that state, and it will not give any benefit for the other state as labor must turn into some needs of people like house, car etc. in their state. Even we block commercial agreements against abuses for this reason, still we may not escape emerging problems like this. Also the states like USA will not accept the situation. We must determine a special condition for United States for their using of own production freely; so instead of common property, we should let states to press their own money freely, and we should do exchange between states, international trades. Any state which has not been producing any production producing in the world will be in debt because of some international exchanges, and the debt only shall be cleared by productions in the other name labor. This seems as the best. Otherwise, it may stay as a needless fantasy as actually there is no difference. We should stay away from needless charges. When a trade is done in your country, you will pay cash it; but the buyer state will pay it later and then an exchange will be done by some periods.

Also as I said, a time ago, I published some articles about Heisenberg's uncertainty principle $[1,2]$. It was about emergence of the universe, and shows us, that how matter does works and can produce free energy by using its own emergence energy each second without consuming itself, like still only emerging instead of working. Also I found a closed system thrust engine independent of mass of air or water, that we can gain more acceleration and top speed than jet fighters in the same volume. If is the below, there touched on some industrial changes which have been looked for still and are required for more advanced civilization based over that articles. The main aims are cost, effectiveness, and producing speed, and ease for these changes as engineer work. There are some new technologies and techniques for buildings, roads, work machines; air, sea and space vehicles; vital structure of cities like water production and purification without energy cost, heating and cooling are included as well by only one-time spending material cost. These civil engineering materials for vital infrastructure of states, are pretty effective and extremely cheap. Let us investigate these materials with some small technical details under a new title as the below.

\section{Technological upgrades for vital infrastructure of states}

There are three basic functions, that existence works and lives over them. They are pure energy, heat and motility. If you do not have a problem with these elements, you shall have no problem to create an advanced civilization; but in our age, it is too hard to use natural resources as the most effective manner because of the required labor, time and methods as there has not been another alternative yet. Scientists have been working for years about perfection of engineering materials and methods to gain faster, more secure; time, labor and money saver methods.

\subsection{The basic functions}

\subsubsection{Energy}

As energy, it is the basic requirement for the continuation of life as it keeps existence standing. As I said [1,2] there are some ways to generate energy free manner by using matter's own creation energy. If I should make a brief explanation, as constant acceleration motion is not possible, then for two different $t$ values in $x(t)=a t^{2}$ and $v(t)=a t$ functions, will change functions even for the smallest time change. For $f(x)=a x^{2}$ where $a$ is any acceleration which is fixed or not, over $f\left(x_{n+1}\right)=f\left(x_{n}\right)$ equation where $x_{n+1}>x_{n}$ and for the same distance taken magnitude between two different times, the equation becomes Eq. (1).

$$
\frac{a_{n}}{a_{n+1}}=\frac{t_{n+1}^{2}}{t_{n}^{2}}
$$

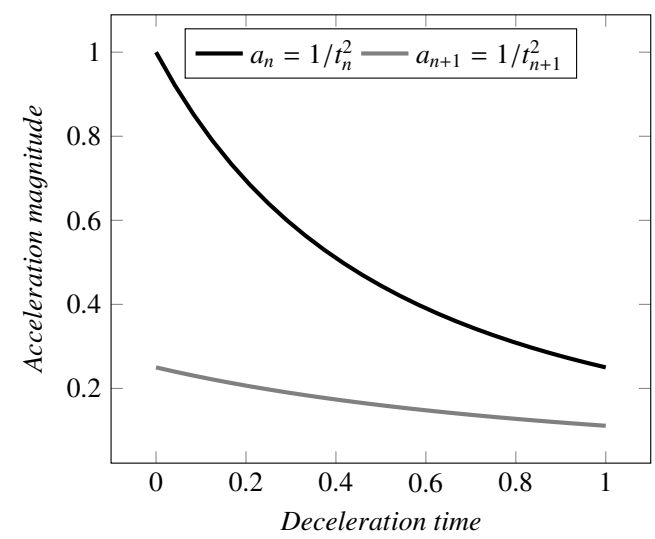

Fig. 1: Deceleration for a limited interval

There is a presentation of the motion as Fig. 1. Hence it can be said that, $a_{n}$ which is one of the previous acceleration magnitudes is always bigger than the next $a_{n+1}$ magnitude; therefore the universe is decelerating from an infinite value as a virtual part of absolute space, in a time interval and by having emergence time priority for each small point of emergence area. It has to emerge by frequency, and there cannot emerge a point which has absolute emptiness namely nothingness. Already acceleration is not possible from zero point namely from nothingness because of previous motion, and already if constant speed and acceleration motion are not possible, it means that already motion emerges by parts over time at infinite frequency which means no constant speed even for infinite small work part. Otherwise, it requires to be absolute.

It does not differ for matter, that it is created or it does work. To be more valuable of a vehicle or device does not mean for matter it is valuable. Matter is doing the same work for any material and work even if it is static or is moving. At that time, it is only emerging.

Matter is a part of infinite. You can neither detract anything from, nor add anything to infinite, since everything an element of the infinite; so matter is created by forcing each second as an absolute must do the work instead of the created one, and is created by a repeated motion. This means that matter is absolute inert. This means $m v^{2}(J s)$ energy potential for a formation velocity of $v$. As formation will be in changing values during 1 second, energy must be shown as $(J s)$ which means "Joule per second", and also mass must be shown as $(K g s)$ 
which means "Kilograms per second". These things mean that we can use matter's own energy each second by using matter itself without spending it and external energy resources. As it always does a formation motion, still it will be doing a formation motion.

$$
\varepsilon=-\frac{\partial \Phi_{B}}{\partial t}
$$

Eq. (2) is Faraday's law of induction, and it states that changing magnetic field produces an electromotive force $(e m f)$ in Voltage unite by creating a potential difference and an electric field.

Handle a simple machine system which provides force efficiency and generate electricity by a lever by $L d_{1}=F d_{2}$ where $L$ is load, $d_{1}$ the distance of the load from the center of gravity, $d_{2}$ is the distance of the force applied from the center of gravity. For the load which requires $E$ energy to be lifted, the equation becomes Eq. (3),

$$
F x=E
$$

where $x$ is the distance taken while applying the fixed magnitude force. If the used magnetic flux is increased by making magnets bigger gradually forever for the fixed force efficiency distance of $d_{2}$ which is the other hand of the system, even if the magnetic flux change number is the same, it becomes Eq. (4) as the distance taken of $x$ must decrease to produce the same $E$ energy for the same magnitude force.

$$
\lim _{\varepsilon \rightarrow \infty} x=0
$$

It also requires to be 0 of the work done. The distance taken for each change must decrease at the amount of the enlarged magnets for the same force to produce the same amount of electricity; thus the work done decreases even if the generated energy is the same or increases. Finally even electricity can be generated without external energy, that means zero external work done if it is used big enough magnets. In a high magnetic field, self-inflicted electron flow which means electricity can be detected beyond the same order of spins because of electrons' movement which occurs at different distances around their atom. Even if the high violence magnetic field is fixed without change over time, the movement of the electron which does not jump another atom in this magnetic field around its atom can be counted as magnetic flux change. This work is done matter's own energy as matter is always together with a motion. This is like the condition of a gearwheel spinning at a fixed speed. If you give a handle to the system, the gear will hit the handle forever and will work, and the gear's energy is in God's hands. We can force matter by some incitements to work in the name of us by using some amounts of its own $m v^{2}(J s)$ energy for a formation speed of $v$.

Also $d_{2}$ can be lengthened to catch the same effect if magnetic flux increases; because when $d_{2}$ is lengthened the force magnitude will increase and the distance taken will decrease automatically.

But here do not make a calculation like in classic mechanics. For example, if you accelerate a magnet on a rail by $+F t$ work, by required assembly with $A, N, l$ coil values and the other wire values, assume that at the entrance of the coils during its motion, two poles of the coil are connected to each other and so the induced current's magnetic field stopped the magnet by the same $F t$ as $-F t$. Here, the work done by you to accelerate the magnet is $F x$ but the work done by the coil is $F x+E$ where $E$ is stored energy for example in a capacitor; so you made magnetic field worked. Even if you do not use magnetic field of a magnet, it does not mean it does not work at that time. Also while you are using it, it does not mean it worked; so for example by a lever like this shape $\vdash$ that the intersection point of perpendicular two lines is center of gravity and is fixed from there to rotate of the system, assume that there is a magnet placed as $S N$ at the top of the vertical line, and there is the same magnet bottom of the same line as well. While you are making the lever moved towards the bottom from the end of the horizontal line, the emerging opposite magnetic field from top will push the magnet and your force applied back but the other one which was placed at the bottom will help you as the pushing will be in the direction of your force applied when you use it as a electromagnet like a coil gun as the ratio of magnetic field and current as $B / I$ is independent of current. You can catch the same effect in a rotating field by two the same rotors; but one of them will be rotating in the opposite direction that it can be provided some simple gears, that actually even by a single rotor, it is possible as well. This can be realized even by a single magnet as well; because the calculation is not like done in the classic mechanics. Otherwise you make mistake and it will be hard to understand. Changing size of magnet and its magnetic field, distance, coil and wire options for the same amount of conductor will change everything.

To be more clean of it, I think that I should explain it more detailed.

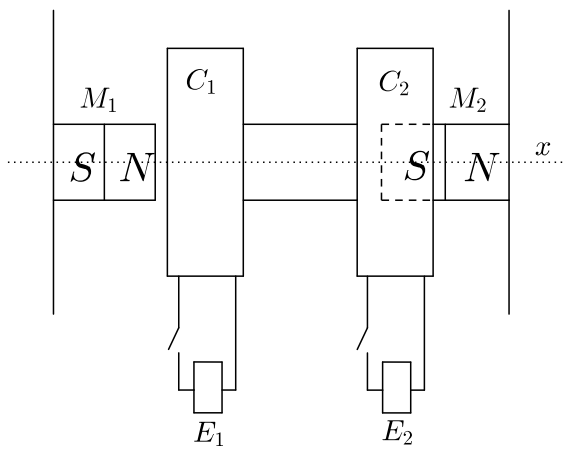

Fig. 2: Generator

Here, $C_{1}$ and $C_{2}$ are coils that are connected to each other by a material, and $M_{1}$ and $M_{2}$ are fixed permanent magnets on the walls. $E_{1}$ is energy source like a battery that voltage and current are always fixed. As $E_{2}$, it is a power storage unit. The coils are able to move right and left on a rail on $x$ axis. When both of the switches are closed at the same time, naturally first coil becomes an electromagnet and moves towards left namely the first magnet due to the direction of the current. During this time, the second coil is also moving in the same direction since both of the coils are connected to each other; but the second magnet will be inducing electricity on the second coil. Now, repeat the same action from the standard position by changing the first magnet's size and magnetic field forever gradually after switching off near the wall while moving the coils to the old and standard position. What happens there being the coil sizes and the current, the voltage from the energy source are fixed. The attraction between $M_{1}$ and $C_{1}$ will naturally increase for the condition because of the enlarged permanent magnet of $M_{1}$; so $M_{2}$ will be able to induce more electricity on $C_{1}$ since change in magnetic flux relatively to time will increase. Here, the work done by $E_{1}$ will always fixed since energy is fixed for $C_{1}$. The work done by $M_{1}$ will increase, and if you use bigger $C_{2}$, also you can generate more electricity because of the 
attraction emerges between enlarged $M_{1}$ and $C_{1}$.

Also it is possible without magnets; because the ratio of magnetic field and current as $B / I$ is independent of current; so many different size magnetic fields can be created by a current or induction can be realized for fixed magnetic flux change amount by changing properties of the coil and the same weight wire if you risk heat for more. Actually this can be used for thermoelectric generators to create heat difference.

Already because of the time differences, between each point of space that means emergence priority,

$$
\varepsilon=N_{2}-N_{1} \frac{\Phi_{2}-\Phi 1}{t_{2}-t_{1}}
$$

shows, that it is always $\varepsilon>0$ where $\varepsilon \in \mathbb{R}$. It means that a coil even placed at infinite distance from a magnetic field has a voltage difference between the two top of the wire. If there is a fixed matter in the core, voltage will increase. If there is a fixed magnet in the core, then even if also the coil is fixed, the voltage will greatly increase; so it means that even by switching two fixed coils have permanent magnet core and have different resistances will cause magnetic flux change; because electrons' orbital will slide even a current will not emerge, that it can emerge by required assembly and switching repeat. Maybe we can create a micro generator like producing a CPU that sheets between two permanent magnets will be connected serially to create high voltage difference to create current beyond sliding orbitals.

During generating free electricity, if you ask to matter like "What are you doing?", it says that "I am only emerging and doing a creation motion."; but at that time it is generating electricity relatively to you; so do not drain away the power of universe. Just use it.

\subsubsection{Motility and thrust}

As producing thrust, as energy is not independent of force, it can turn into force. To realize this, Eq. (5) or if a blade is used instead of a marble placed at the top of a wire, nearly $F / 2$ centrifugal force is perfect closed system thrust engine potential as independent of mass of air or water without opposite torque, and it can store huge amount of energy by a small energy amount when it is required, by some transmission, that the work done is only done against frictions at that time.

$$
F=\frac{m v^{2} \sin (\alpha)}{r}
$$

More thrust than jet fighters can be produced in the same volume without fuel and other external energy resources even by the electricity generating methods.

In classical propeller systems, you must hold on air to produce thrust by propeller blades; so the mass for the energy of the work done is directly must be the vehicle which is aimed to move; but by the above stated method, you can only calculate the mass of a propeller. It can produce thrust as much as tensile strength of the used materials for the propeller and the blades.

Also if it is connected around a rotating wheel, you can produce torque for any machine.

\subsubsection{Heating and cooling works}

As energy is not a problem, heating or cooling can easily be realized for buildings or vehicles. We can heat a pipe solenoid coil by electricity and then the air flow is going to be hot. If you put it in a container or wind a second pipe around it and vacuum the area, then the coil is going to be cold and thus the air flow is going to be cold as well naturally. Instead of it, maybe we can put the pipe into liquid air as well as we need small machines which are able to work more than their sizes. These effects can easily be provided instantly and constantly.

\subsection{Civil engineering materials run over the basic func- tions}

As energy, heating or cooling, and thrust are not problem, and can be provided only by one-time material cost, it means that we will have more playground to use new methods or we will be able to include some weak systems and methods for the current situation in our borderlines. There are many ways to do it, and they can be sortable as the below. We can remove electricity and communication transmission lines at worst by some workers have back thrust engine, and by some manned or unmanned aircrafts which I told about them the below.

\subsubsection{Main body of buildings}

Materials are able to endure millions of tons by a few tons of material if you use enough surface, height and width if you knit a structure for example by some steel rods like $1 \mathrm{~cm} \mathrm{x}$ $1 \mathrm{~mm} \times 1 \mathrm{~mm}$. If you build a building, you must knit any point of the building area. Stress will not be so much as it will do a coil spring mission. Even you can simply use some cubes made of these rods being the rods are only on the 12 edges of the cube. It will be extremely cheap and light, that if you build a $200 \mathrm{~m}$ x $20 \mathrm{~m} \times 20 \mathrm{~m}$ building, it will be nearly 1 ton, and can endure millions of tons as the load is going to be distributed load.

If we can find some vector lock methods by some steel sheets instead of the rods, we can do the work by hand as the fastest manner in its place, first by producing by some machines fast manner for example by using some $10 \mathrm{~cm}$ x $10 \mathrm{~cm}$ bricks which the inside is fulfilled by polyurethane foam spray against heat, sound and insects. By this way, we do not need many welding points. Just some points are enough. Even solder is enough. 3D printers will be saver.

Actually we can use metallic foams instead of the knitting method. It will also be more than enough.

\subsubsection{Civil environment}

This method can be used for apartments, private houses and factories as it will be very strong and light. We can save our natural resources. The buildings knitted by these $10 \mathrm{~cm} x$ $10 \mathrm{~cm}$ bricks by hand, will be like created by 3D printers as one piece and have very thick walls, that for example start by 1 meter thickness. As there are not going to exist column and chord, the rooms will be perfect rectangular, and each wall between the rooms will has the same thickness. Already the center of the building will be very dense. There must be some mass cells independent of each other, that for example fulfilled by pebble. We can use also cheap stones which are at the same size with the bricks at a frequency. The buildings can be built as reverse $\mathrm{T}$ with skirt fulfilled by pebble to be weight of it. We will not use cement even 1 gram. The bricks will also lock each other. We will use sticky wall decors instead of plaster or cement, and they will not look like sticky. House base also will be sticky base, that will be like cotton. As heating and cooling are not problem, the buildings will heat or cool themselves. They will have personal generators that they generate their own energies without external energy and thus energy 
cost, and the generators will be manufactured as 7-8 Kw generators.

Naturally, the same method can be used for the buildings have huge volume without column. It is required by factories or for example stadiums. $500 \mathrm{~m}$ x $500 \mathrm{~m}$ x $100 \mathrm{~m}$ building will be 250 tons if it is fulfilled without an environment which provides movement. Even the top and the walls will be very thick, the buildings like these ones will be pretty usable and effective, and have incredible capacity as they will be very strong as well against any effect.

Also it can be used for one-piece bridges even for the bridges like Bosporus Bridge. It will be like rod lying on its side. By the way, even it is possible to make a stone covering surface. This method also allows many shapes in the point of architecture, and has a good potential even for extreme engineering.

The same method can be used for one-piece huge campuses for education, hospitals and stadiums; for rally stadiums have million capacity which are like 3D printed tracks, that anybody can watch the current position of pilot; for floating or flying cities and farm areas; for airports which have for example multiple flats that each flat has circular take-off area on a circumference for the air vehicle I told the below.

We can also use metallic foams instead of the knitting method for them.

\subsubsection{Roads}

The same method can be used for building very wide roads. Steel knitting roads will be pretty long lasting, strong and so good. Also it can be built very fast. We can use heating systems by the self-running electricity generators. We must build any road has 200 meters width. It will be cheap. $1000 \mathrm{~m} \mathrm{x}$ $200 \mathrm{~m}$ x $0.1 \mathrm{~m}$ road will be nearly $250 \mathrm{Kg}$. We will only use 250.000 tons -300.000 tons of material for 1 million $\mathrm{km}$ road; so a road like this will be maximum 10 billion dollars with the heaters and the generators.

This roads will have thin copper pipe system against ice and even for rain. The generators which are built on a side of the road by some intervals will not be so strong. We do not want them that they will melt very thick ices in seconds. The generators will heat some solenoid pipes have smaller resistance than the system's resistance without stress as the same as the system which I told it the above, and will blow air out slowly when a snow emerges. They can be controlled by required units as remote controlled; but also they can run autonomous according to environment temperature. Responsible state unit can scan hundreds of meter squares in minutes by the air vehicles which do not need external energy and thrust support, that I told about them the below. Almost there is no engineering for these roads. Almost it can be done by material costs.

\subsubsection{Vehicles}

The same method also can be used for air, land, sea and space vehicles. As roads will be very wide, also we must build more secure vehicles for the perfection. For example, personal cars maybe will be manufacturing by having $3 \mathrm{~m}$ x $6 \mathrm{~m}$ x $3 \mathrm{~m}$ dimension by the same method. When this is done, the empty car only will be nearly a few kilograms without engines. If you build a cylinder which has a generator inside, and if the surface of the cylinder is able to spin, and if you use small thrust engines with generators or electricity motors work by induction from the environment on this surface as a fully closed system engine that you cannot know is it an engine from the outside like a wood waiting to be cut, as you can gain much more torque, also you can obtain motility for land vehicles or machines as well by this torque.

Also we can use propeller for the same work. We will determine the required number of this small engines, and connect them circumference of a propeller again. This propeller's blades which have these engines can only be create angle downwards when it is parallel to ground at the standard position. If a system issue emerges and the propeller's blades want to create angle upwards, it will hit a cover. This system is also for land pressure against the car's weight. Land pressure and the torque for the motion of the vehicle will be produced by the same engine maybe at the same time in the required amounts relatively. This torque system is important; because if you directly use the thrust engine on a car, the tires will be independent of the engine and so will be pretty dangerous in the point of car controlling. The angle will change when the car starts to be faster, and the system provides more land pressure during this acceleration. As the car will be pretty light, we do not need big generators, and we can make it move anywise by some small $10 \mathrm{Kw}-20 \mathrm{Kw}$ generators. Already the system will not be so big, and as it stores energy we do not need big generators as we provide torque by some transmissions as the propeller always turns at the same speed, like a reverse brake system. The car like this car will have maximum 100 $\mathrm{kg}$ weight even if it will have a bigger volume than the current ones; so it will have smaller momentum even for high speeds. Also all the car will be doing spring mission against shocks emerge from any side of the car. If anybody has the same type cars, then an accident will be more secure according to emerging momentum of the both cars, and also both of them will be doing a spring mission. Car heating and cooling system also will be the same as I told the above. The tires should also be produced by the same method as puncture proof tires. Tires should be wide, and we can provide suspension possibility in tires by some intervals like 1200 degree. As the car will not be so heavy, we do not need strong and big materials even for suspensions and brakes. Just one central disc which all the four tires are connected to it in the engine's environment is enough I think.

The same method can be used for air vehicles and ships. They should be pure prefabricated. We only create an area and make sit required parts on its own place. We should not manufacture as one-piece. We should manufacture some $5 \mathrm{Kw}$ $-10 \mathrm{Kw}$ generators and should use them as parallel. There should not be a part which cannot be carried by hand. This must be standard I think for flying passenger ships or planes, that captain will be able to make a passenger worked for replacement in a possible the worst condition. By this way, also we can carry their replacements. Air vehicles must take-off vertical manner by these engines. The engines will be manufactured as cylindrical as stated the above, and only sit their places, slots. We can gain any vehicle motion in any direction by only two engines placed reverse manner and are able to move in any direction, that these two engines provide thrust in opposite directions. The air vehicles like these vehicles can be used in ports instead of winches. We can build flying cargo and passenger ships, that they can only cruise on sea at a small distance from surface of sea.

\subsubsection{Work machines}

\section{Tunneling machine}

As energy is not a problem, we can produce liquid air at anywhere by pressure. We can spray it to drill. Combine your 
tips of fingers without an angle, like an umbrella. Think that there are three heads to spray it, has 120 degrees among themselves. This will create different tunnel radius. If the tunnel destroyed, as the radius can change, the new vehicle can enter the tunnel even if the rest had been already built. These heads have many spray points on the surface. Also between these points, there are many vacuum points. Each of these 3 heads rotates around itself, and also the platform that the heads are connected rotates around itself. Even we can cut steel by this method. It does not need more maintenance. Also there will no powder or another dirt because of the liquid air. Even if a powder emerges, it is going to go into the liquid air and is going to be a mud by vacuum. The vehicle should be controlled remotely in a security armored vehicle has life support unit includes air or air and water generator from air by the ionizing method stated the below. There should be some laser distance meters on the head surface for autonomous move.

By the same method, we can search water. Just we need a vacuum hose which is supported by steel to keep very long and slim machine. Maybe the pressure can be created at outside, and is given by a different hose. The machine will want to move back because of the pressure but it can be balanced by the engine. We do not need portable weight.

\section{Firefighters}

By the same torque producing method, we can produce liquid air and spray it from plane or land vehicles. Liquid nitrogen has a powerful diffusion explosion because of its vapor pressure. The fire will create an explosion and it can finish the fire. Liquid oxygen will affect the condition; but constant explosions because of liquid air rains are very deathless even for liquid oxygen. As the knitting method will be used, the air vehicle will be very light and have more than enough volume. We will use thousands of the same spraying and vacuuming small systems on the same vehicle.

\section{Monster trucks}

The same method can be used for monster trucks as also these trucks can be manufactured as air vehicles. Land vehicles like this should have like $30 \mathrm{~m}$ × $10 \mathrm{~m}$ × $5 \mathrm{~m}$ dimension, and also should have very wide tires instead of high ones to distribute the load on the steel or silicon carbide knitting very wide roads. Also like this vehicles should have $10-30$ trailers as the roads are very wide.

Actually a new type air vehicle can be used for soil transporting. The tunneling system also can be used for air vehicles like UFOs, I mean for the vehicles have a simple geometry. We can provide GPS support, and the vehicle can work for required height. It will look like sinking into underground in a mud because of its weight, as actually it will dig the ground from the vehicle's base by many vacuuming and spraying holes. They should be built as unmanned vehicles.

\section{Farm machines}

The same methods can be used for farm vehicles. As they will be more powerful, they do not need energy. Also we can use the thrust engine for the deepest plow, as actually the same engine can be used for land pressure. We do not need portable weight.

\section{Supersonic trains}

As roads are very wide, we can build at the middle of the roads some supersonic trains in a closed environment by the same knitting method. Its walls will be between 10 meters 20 meters. Even the train carries thousands of people, as it will be very light, its momentum will be small like a train going at a walking speed. The train will move on three circular rails have 120 degrees among themselves, and the tires will be spinning at nearly $20.000 \mathrm{rpm}$ when the supersonic speed is reached if the tires have $25 \mathrm{~cm}$ radius. The tires must be a strong material against both of heat and stress like tungsten, tungsten carbide or silicon carbide. It will not problem for these, that they turn at $20.000 \mathrm{rpm}$ as the train will be light. Use them and then send to recycling. The suspension system will let the train for yielding by the required settings. Just we will leave a gap between the walls and the train against air compactness. The trains like Maglev need much more energy, and also you need external energy sources placed along the path. We do not need much more energy and external energy, if we build them by this way since the engine is going to move with the train. The thrust engine will be enough; but I do not know what about the sound. Also maybe we can use the torque generating method by some transmissions at this trains as well, being the tires are not independent of the engine.

\subsubsection{Industry \\ Water producing: Type zero}

We must build some ionizer systems to separate elements of ground or water. As energy is not a problem, we can build giga factories, that separates elements in electric field, and make them turned in a circular area has a magnetic field by mass differences. It is possible to repeat the same event thousands of time in one second. As magnetic field can do work as much as its own energy, if you send new particles to a magnetic field in a plasma boiler like tokamak, some collided particles will move downward. They can rest in the base of the plasma boiler as it will be very hot because of electron and nucleus collisions, that any element's boiler will be different. If only the speed decreases the energy can be switched off by some periods according to collision time and any particle amount.

As the second work, we must build evaporating houses. We should build some glass pools have copper rods around them to heat. The house should be as a pyramid, and the surface should be fulfilled by rectangular copper pipe bricks have for example $10 \mathrm{~cm} \times 5 \mathrm{~cm} \times 1 \mathrm{~cm}$ dimension to pass of cold air flow. These pips sit on some flats which are as a frame. After that we can send the pure water to cities, actually to city water stores. They feed the pure water by required elements by the ionization method in electric field, before send it to houses. This water will be type zero. Reverse osmosis method is not perfect. You still must pay attention feeding. This method can be used as medical water for some elemental missing of some people according to doctoral advises. Also the same method can be used for feeding farm water. We can produce any type farm water according to the kind of farm product. We do not have to use artificial or natural plant foods. Also the same methods can be used for purification of waste waters.

To send water between cities, we can use the torque producing method, that I told about them the above. The propeller on ground can easily have $10 \mathrm{~m}-30 \mathrm{~m}$ radius. We do not need more energy as actually the engine stores energy; so we should choose the smallest distance to carry water even it passes from the top of a mountain.

The same methods can be used for movable space stations. Even we can build them being they have a few kilometers square area and so huge volumes as they will be movable. As 
they will be manufactured by knitting that I told about it the above, also they will be very light. The engines are very powerful. Thrust is not a problem. Also heating, cooling and recycling are not problem as energy is not problem. As these stations will have very thick walls, we do not have to use expensive materials, that instead of it we should use cheap materials in higher amounts even it will bigger and thus heavier since energy and thrust are not so big problem after this. Just a good armor at the surface like silicon carbide. We can produce this material beside the other materials for knitting as sheets like have $10 \mathrm{~cm} \times 10 \mathrm{~cm} \times(0.1 \mathrm{~mm}-1 \mathrm{~mm})$ dimensions by tungsten press machines seems like car engine pistons fast manner. Silicon is the most abundant element in the earth, and has a hardness near diamond. Also it is not bad against heat transfer to block it, and also almost is not be affected from space cold in the point of yielding; so as it can be used armor, also it can be used for the main frame material for that $10 \mathrm{~cm} \times 10 \mathrm{~cm}$ knitting bricks made of sheets. The same methods can be used for high hypersonic passenger planes travel from space. Also we do not need the satellites like current ones. As we do not need energy generated from space, we can build them as nonorbital and pure closed. The rays can pass through by required energy. Even the satellites can be manufactured at the size of an apartment by the same old technology. We can use bigger transistors for example even if they will use more energy. Just we need some thermodynamics calculations for the environment heating and cooling. By this way, we can manufacture many replacements which can placed on an orbital in minutes at the same cost of a high technology satellite.

\section{Mining}

The same ionizing method can be used for mine production. We can produce any type of element by this way by using scraps or any materials.

Additionally we can bring some asteroids to world as well. The engine is very powerful, and also there is no energy problem. We can use mass difference in electric field to determine asteroid's elemental condition.

Also we can use always the smae engines to collide huge graphite blocks in space to produce any type of diamond. Also we can use it for fusion at a distance far enough. Just we need material. We can use the smae engines again and again.

\section{Some extra offers about current problems}

\subsection{New home}

If you create a continent has $5 \mathrm{~km}$ x $2000 \mathrm{~km} \mathrm{x} 40000 \mathrm{~km}$ dimension, it will be nearly $2 \times 10^{18} \mathrm{Kg}$ for the world's average density. If you handle an aircraft like I told the above which can carry 100.000 tons for each turn of the work, this single aircraft must turn 20 billion times to carry this weight. If you use for example 100 million vehicles like this, each vehicle must turn 200 times.

This is important. The vehicle will be knitted by hand and by using metallic foams, will have much more volume even for its walls, that even still it will be lighter and lighter. Also the engine is very powerful. It will have very small number of parts.

As this vehicle has very thick walls by cheap materials, also it can be easily modified for space travels, and so as we can do space landscaping in other planets by the same vehicles modified, also we can bring to the earth new grounds as actually the world is a unique planet instead of travelling interstellar.

If the vehicle consists of one hundred and twenty thousand pieces, and if you use 1000 workers for each vehicle, and if each worker carries and places 1 part within 5 minutes by working 10 hours in a day, then it means that you can manufacture 1 piece of like this air vehicle. If you use 100 million people to realize it, we can produce 100 million of this vehicle in 1000 days. There are many people which are waiting for food. Almost 1 of each 10 persons is hunger in the world. We can establish new temporary cheap colonies for them at required places like in Africa, India and China. They will work in the name of the United Nations to produce these vehicles. They can spend the money earnings in their states. There will no part which cannot be carried by 1 person. Even the engine or the energy generator will consist of many small the same generators and propellers. If there is no part which cannot be carried by hand, it provides constant using even if the performance will decrease because of unused broken parts instead if not to be usable of the vehicles during replacement and repairing. We do not wait queue. Also the main body will be built by the cubes like the 3D printer drawing method, namely by layer.

By this way, we can create two new continents at the Tropic of Cancer and the Tropic of Capricorn, that each one of them has $5 \mathrm{~km} \times 1000 \mathrm{~km} \mathrm{x} 40000 \mathrm{~km}$ dimension. If you think that each vehicle will go from space by required protection, and will finish the each turn in 2 hours unloading and coming back are included as well, for any long distance even by the earth's gravitational acceleration, we can carry 120 trillion tons soil in one day. It means that nearly in 20 days, we can carry all the required amount of the continental soil which is $2 \times 10^{18}$, and then the shape of the world will be changed. Namely, actually we do not need so many people to carry soil.

Also it will be used for terraforming of Venus as it can make liquid its atmosphere. We can carry carbon dioxide from Venus to Mars. If only vacuum works, we can carry water; so we can bring water to Venus or Mars from for example Europa. All of these works can be done without energy cost and other negativeness by a little number of parts.

When this is done, there is a powerful possibility, that also we can find ancient seeds and animals. We can separate the ground on this continent as we can search it by hand, and will irrigate it. As the continent will be far enough from another land, probably there will not be a seed which is carried by wind.

We have some new technologies to open new places in the world, for dealing with volcanoes and continental movements, to move space stuff. We should melt any ice on the earth. Warmth is not problem. Most of animals, people and plants cannot live healthy manner in cold as water will become denser in cold, as additionally its movement will be affected. Maybe we should carry the ices to Mars and Venus. It is not a problem to bring them back by the vehicles. I hope, scientists think about these subjects and decide to make the world better place, with some miracle ancient plant seeds and animals.

\subsection{Catalans and Kurds}

Catalans have been waiting for freedom for a long time. Also Turkey has almost the same problem with Spain. Kurds in Turkey also have been waiting. Actually most of them are terrorists who are role playing gamers, and use some terrorization methods like Vladimir Lenin. Most of illegal works are under their control in Turkey. Even so they work to make Turkey accept their legitimacy as they believe in this, as actually this is the main philosophy of justice that if you want to believe of someone to accept the crime, first the person must know the crime as a crime, as even nobody blocks Kurd's political rights. At this situation, no state should know terror- 
ist Kurds as rightful as this automatically will be reason for hostility with Turkey, if Turkey do not accept to give land to them like Hakkari, as actually the population will not reach 10 millions, and if they do not recognize Kurds as friendly to be freed.

Also we should demand land from North Iraq and Iran, and give each of them 50 billion dollars as well.

In the name of one world order and the world without armies, as he first move we can establish a Kurdish state there without army. The UN will be guarantor about wars.

We have some new technological potentials, that we can easily fill sea by ground in a short time. At this situation, the United Nations should press money for them to develop the required technology and to fill sea. Even 1 state able to build a new continental by the technologies stated the above as the cheapest manner without energy cost and other negativity; so like 150 billion dollars cash for Spain, and 50 billion dollars cash for Turkey will be pretty good and enough. As work place owners always have a potential because of unsold productions that unused machines and the machines have not worked full capacity, and the workers waiting for work are included as well for example, these monies will not affect the economy, as will improve it in the exact opposite manner for one time. The above stated methods will be safer even for the worst economic situation as the basic functions will be working at any prize.

The same knitting method also can be used to fill sea as the cheapest manner. They can carry even current cities; but the new city elements will be extremely light. We will only fill around the knitted base against water and so deformation. The base can be built as high enough from sea level, and also if the base is built by pieces, the pieces can be changed after a few hundred years. The same method can be used for hydroponic agriculture.

I think Turkey should accept it especially if they use the above stated transformations: because I am so sorry but some big cities like İstanbul and İzmir turned into shit because of the Kurds who have no business. Crime increases because of them. Already any person will have free house without energy costs and some other negativenesses especially about food and work; so why they must serve for them. They should denationalize unrequited people from streets. They should bring out a good migrant law.

\subsection{Syria and Iraq: ISIS}

Also there is another problem called ISIS a strange version of the MIB. Syria and Iraq should use the colony order which was told about it the above. There will not exist district, town or village. Also there will not be another settlement different than the colonies. There will not be a city that any different people live there together, or is related by single kind people. Shi'a, Sunni and secularists should have different colonies by different laws. They must show respect for each other. There are only four main settlement states as North State, South State, East State and West State, and there are colonies named like 127 th colony etc. An address will be like "62nd Colony, 12nd Street, 34th Apartment, Nr: 5, South State/ IRAQ”. They should build a race track which is also used for driving learning track has 200 meters width fully-closed manner, around the circular colony. As also it will be a wall, there should be 4 entrance of the colony. Anybody should be controlled at the entrances. Also they should build some squad castles according to howitzer range. As each colony is autonomous, each colony should have a squad castle and they should only accept soldier from their own colonies. As state works will be distributed on colonies, also it will not problem how the state will be managed except the king, and the main government as actu- ally it is not a problem. For example a women cannot walk in street without hijab in a colony; but in another secular colony, nobody will be interested in hijab but there cannot be counted as Muslim colony. There cannot be a mosque, and they will worship in their houses. Anybody will think "I have a trillion dollars money to establish a work place. What will I do? How can I find some joint to establish to use the money?" if they apply the articles of the constitution above. They stay at their own free houses until they find a work. The state will not be affected economic problems, as the main functions will work forever at any prize. If they are volunteer about trying this, no nation will recognize their monies. They will be able to press national money as they wish; but if a person, company or institution in that state does shopping international, then the state which did the shopping is going to take instantly the national money of its own customer, and also the foreign state which is seller will pay instantly for its own seller. By some periods they can check the current condition up, and act required manner. Maybe they can determine a quota in the reciprocal relations. This can be counted as exchange.

There will not be energy, shelter or water problem forever by the above stated methods as the cheapest manner. We can build a colony has 1 million people potential and has 100.000 people capacity, schools, universities, work places, houses and hospitals, stadiums and roads are included, by the same amount of material which is used to build a few super tanker by the knitting method.

We should build some sample cities, cars and trains by the methods stated below almost from today to tomorrow, and should talk to ISIS to finish the rebellion. They should help their own states. They should work for their own houses.

\subsubsection{Sunni and Shia}

Actually Sunni and Shia should watch the ways of agreement and moving together by excusing the great change. According to me, the actual problem emerges because of Shia; because except Khalif Ali who Shia follows him, everybody has been talking something about the famous conflict. Once Prophet Muhammad was talking to his companions, and said that "I am the owner who Ali owns". If I did not know Khalif Omar who is actually can be counted as an enemy according to Shia said that "Congratulations Ali, that you became the owner of any Muslim.", I would say that Muhammad left a new man for his family, that once Muhammad said "O Ali, I gave to you the right of divorcing my wife Aisha in the name of me." when Aisha made Ali angry that Ali saw an unqualified behaviour from Aisha against Muhammad, as also the speech was a farewell. This is the same thing, that mothers sometimes say for their male children the same thing when the father of the home is not there. Shia counts this an absolute superiority reason. They are right partially; but the actual sentence should continue like "Ali is better than those people about those subjects, those people are better than Ali about those subjects; but the actual superiority is counted this.". Ali and the other 3 highest companions can be counted as equivalent of each other partially; but there is no evidence for an absolute superiority to take Ali to the top. During the same speech, Muhammad said, that Ali is khalif after him; but companions elected Eba Bakr after the death of Muhammad since they knew that he is the highest authority after any prophet according to Muhammad. Shia says it is unjust. It is not unjust; because it does not mean the immediately next one after Muhammad. It is an information about the future of Ali since Muhammad was doing a celebration and publicity. Already Ali said nothing. There is no 
information about the complaint of Ali about this subject; but even so everybody except Ali says something about it.

Already it does not matter who is right or wrong. We must be patient; because God did not send a holy book as one-piece as also he did not order his prophet like 'look at this book and punish the criminals without talking'. They cannot count each other as unbeliever about such a subject since is a simple mistake actually. There is no premeditated thought as there is actually a negligence. This does not require to be unbeliever. If it requires, then most of the Muslims are unbeliever now; because they say that Muhammad is the last prophet according to some declarations of him and to a verse. This is not right completely. According to Quran, a new prophet shall come as an obligation; There is an article about Muhammad. The part of the 40th verse of Al-Ahzab says Muhammad is the last prophet; but actually we must translate it as 'last of the prophets'. The article here as 'the' does not mean black hair prophets. It means the prophets who have own holy book as a head teacher like Moses or Jesus. Jesus talks about a hero called Paracletus means helper in Bible, that also says he has no superiority to Jesus and Jesus shall live together until the end of the world. Also Muslims believe in a hero called Mahdi according to Muhammad. Muhammad says, that "Any prophet has one sign on his right hand which is an evidence of his prophesying but me. I have this on my back; but only Mahdi has two signs both on his right hand and on his back.". Why God will give a prophesying sign to a person if the person is not a prophet, that even will give two signs being the person is the single owner of the two signs in prophets the biggest and the bigger ones than Mahdi are included as well. Namely, an assistant prophet shall come, that according to holy books he is called the king of kings being the most powerful and the biggest assistant prophet existent. What an assistant that Jesus shows modesty and says for him 'the real owner of this realm'. He is like Joshua and Aaron of Moses or Solomon of David. The head teachers are their doctoral advisers. Already Muhammad says, that Mahdi shall not come with a new holy book, as he shall follow Muhammad. As the two signs are not an evidence of the absolute superiority of Mahdi, also some compliments about Ali does not mean he is the best, as additionally no Muslim became unbeliever since they could know know the reality yet.

As a result, they should live their own colonies by distributing their problems on time. They must show respect each other.

\subsection{The Gülen movement}

As the Gülen movement of Turkey, even if the rebels are exactly criminals, Turkey also cannot be counted as innocent as well according to me; because as far as I saw, at the beginning when there is nothing in the name of a conflict, the government wanted to close all the private classrooms. There were many classrooms which belong to the Gülen movement in Turkey; so the communion of Gülen started a hard criticism over press against the government, and they said that "Erdoğan left us alone". After that, it was said that the act of the government is a part of a plan which aims finishing the Gülen community, and the required decision was taken during national security council meeting in 2004. Maybe there are more but I heard two different statements from the government officials like "The decision is not binding" and "The decisions taken here are not interested in anybody". According to me, Erdoğan lost trust of the community after this. Thereupon, the community started wire tapping against the government by using state possibilities in their hands to learn what is happening. Af- ter that, they were busted, and are recognized as parallel state as traitors. Thereupon the state wanted to close their institutions. Erdoğan gave an interview on TV and said something like 'they had been infiltrated their men into army, they had been infiltrated their men into judgment...' by enlarging his apple of eyes that actually means "How could it be, I did not see anything". Actually Erdoğan knew their actual aim and thus also he was one of their supporters. The aim was placing more just persons who can create more free environment especially about religion in public. Like the secular people there, they were educating their own children by some hopes like good state places with a religious and humanist perspective that they are humanist people. For example, they were informing their friends about Public Personnel Selection Exam. Namely, even I could not know the actual intention of Erdoğan, this worked for Erdoğan if he also aimed this, that I heard a few years later from the impact attempt from Erdoğan on TV something like "We want to close the classrooms because of this reason." by meaning possible betrayals while he is talking to support the new law constitution.

It is terrible that maybe all the things happened because of a misunderstanding. Namely, the government thought that if any community gets bigger enough one day, maybe they cannot control it and are abused by foreign states; for the future of the state, we must determine some limitations. Maybe they were right; because you cannot manage such a big community without autonomous managers. You cannot talk to them always; but the method was too wrong if this is the situation. Already one of the actual problems to establish such a big community still remains.

According to me, the main aim was not military impact to establish such a big community. Already it is impossible to capture a state from inside by this way namely without public and by only some important persons, even by a military impact. If nobody supports them, how can generals or soldiers work in the name of us and instead of us in such a big state works. The people were ready in successful impacts in Turkey before. Namely, only they can damage but capturing, that actually for the future of the state and in the name of providing freedom, you must risk it according to me if there is an unjust system in your state that there exists in Turkey according to me. Already the situation is not different than political party. Still you can find many manager who are threatening the people who are not in accordance with own idea.

As Fethullah Gülen, when the community was busted during wiretapping, he said so heavy things about the people who realized it even when there was nothing related with an impact; but however continuous problems were directly related with him even if he still was defending himself during this period. After the impact, Also some army personal said he gave the order. I do not think so; because charging someone is not so easy. Even you cannot let a person who always praise you and is head supporter of you to think like 'I can move this move instead of my friend. Already nothing will change even if I talk about this subject.' even the person is really trusted person, that maybe Erdoğan thought such that in the name of Turkish people against waking up the community. This is required in the name of to be clear. If you do not behave like this, as this includes crime, also you must be counted as slanderer. Namely Erdoğan must be investigate even his own friends and supporters beside the community more detailed if he does not want to draw a criminal appearance. You must play open-handed. If you do not have enough evidence to charge someone exactly, as justice cannot count you responsible, also God cannot. Some people said to me, that how cannot Gülen know what his 
companions do? Then how could not be informed Trump before the head of intelligence made an agreement with Turkey about kidnapping of Gülen to Turkey without asking Trump, that the head was fired by Trump. Some autonomous behaviours are easily possible. They may think like 'this is right and we do not need ask about it to our leader'. Maybe some people did not like Erdoğan between them, and also maybe they used the community. Otherwise then also Madonna raped me.

In Turkey, maturity level of secularism and democracy is only a claim. According to a tale, everything is okay; but for many long years headscarf women could not enter an institutional environment of the state; because according to the secular people, a state and a religious order are different than each other. Actually they escape it, that this gives a right to the families of that women and the other religious persons to say "Okay, I accepted; but as long as you give me living right, as nowhere left for me but the streets and my private house, then also you should start to find another way to go home."; because really it is nonsense. Already as people are forced to think like Mustafa Kemal who is one of the greatest leader of Turkey by laws, and also as people forced to behave like an artificial intelligence which works by a few lines code by this way, in such an environment you cannot wait for evolution of democracy and respect because of the people who what they can and will say had been already determined even for the speech texts. In our history, there is no loyalty for personal opinions like this but loyalty for office itself whoever placed there. Already, for example also America made many wars against both internal and external enemies. Even only Japan took people by million from them, as also they left. At the end of a challenging process, they established their own states. Still they take their own decisions oneself. If you say them that after this you will go under the yoke of that person's thought without any other choice and without criticism as also this is the law of the state after this, then as their soul shrinks also they declare war upon you as also caused civil war during the history of Turkey.

\subsection{Application of secularism in Turkey and possible transformation for it}

Most of the secular people believe in that Mustafa Kemal was Muslim as also they believe in a secular also can be counted as Muslim. Yes he was Muslim; but he did not die as Muslim. Mustafa Kemal was atheist but is humanist if we look at his some speeches and opinions about religion. This happened afterwards. Actually it can be said, that he was like Alexis Tsipras of Greece. This means, that even if I do not believe in a religion, as state and statesmen exist for its people, I shall give what Muslims, Christians or Jewry want from me. As I can realize it by pressing or translating holy book, also can realize this defending by army as the same as Tsipras has to take and make it taken the required war decision if someone attacks Vatican. Certainly such a statesman will talk like 'our religion' while talking to people since the majority believe in that religion. His authority requires this.

Some people and statesmen use Mustafa Kemal as propagation material in Turkey. It also was done to fasten the revolution of Vladimir Lenin. Namely there are much more pictures, effigy, statue and oration of him everywhere especially in state institutions. Children are forced to learn his thoughts by many lessons in schools like done for Lenin; but his hellafast class murders were ignored. Is it not right, that was for the future of the state?

The conflict and the schizophrenia experienced in public there are result of a wrong business of people by state and by wrong information. Quran talks about a genie in Al-Jinn, that he says "Apparently our brainless had been said things back and forth about God." by aiming the Satan who is the brainless and the head ancestor of genies. Actually their exams are harder than us since the Satan is the head ancestor. Namely, as you can see the method is the same in any condition. Satan also educated the genie according to his opinion.

By 2018 even if the situation is better, the secular people blocked Muslims in state institutions. Partisan media was searching news against secularism, that even they used the smallest thing as a news since according to them is against secularism. Also it was a high possibility that the secular state was listening their phones. I think, that because of these reasons, the Gülen movement was using a software called 'bylock' for communication. Even if this seems includes risk for the future of the state as is a crime, according to me they have a strong excuse; because a state is common property of public, as it must answer its people about any subject. Against any possible negativeness, it must investigate like a doctor not like Pharaoh, by analyzing realities theoretically, and then by accepting practically. It must do it in the name of the future of state and as a requirement of justice; because as you know 'justice is the basis of property.'. If there is no justice, there are rebellion and destruction or it means it will be soon.

Yes they caused death of many people; but such a rebellion cannot be counted as terrorism. When you say to someone like "Do not do immodesty", it does not mean the person is absolute immodest. Just the person was doing at that time. They are very different things. Actually also Turkish people and the government are not so innocent about this rebellion according to me. Both of the sides are believer people if we assume that they are not secular. Muhammad says there is no difference between a causative person and the person doing the cause. Once Erdoğan offered secularism for Egypt, and in following year a military impact emerged by Sisi there since Erdoğan rendered this foreign thought as natural and can be realized easily. Erdoğan said that it is not atheism. By this way, the previous president Morsi stayed as reactionary. Sisi could gain a serious support, and said that 'we just moved...'. Yes, the man who called soldier gives such answers that are formed by intelligent smelling short sentences, and without losing courtesy in any condition. As a result courtesy is important especially for military. He was talking to the young people in his country that said he had been lived for many years being there is only one bottle of water in his refrigerator. What a poor ability that Egypt has not been experienced such a big famine in the history of Egypt. Already such a person either becomes transvestite or a putschist who causes trouble in own state. After the impact, more than half of the people did not vote for the selection of Sisi; because they believed in was not formal and Sisi must had left. By the rest of the people, he was elected. When we looked at the back from today, really Egypt had been managed wrong manner, and now because of Sisi, finally dollars are flying on air more than enough. Satanity is not a different thing than this. If Sisi does not like, he fires economist. Right, even if he does not know anything about economy, if he says he want the best, and if it does not happen he can fire. Erdoğan just cried after the people died.

In Turkey, the number of arrested people increased by over $200 \%$ during service duration of AKP. It means that one of each 300-350 people was arrested. The psychopaths who talk such as 'What are you looking for?' without any reason do not become inclusive of people at such a frequency. Half of the arrested people are married people, and most of them were arrested because of some crimes like theft. The economy has been fixed for nearly 40 years. Thee is no difference between 
these years. This means that we could not produce even if there is a satisfying technological infrastructure improved and developed without state support and planning by industrial professionals. God sent a dowdy person to Moses, and said that 'he does not recognize you and me; but as I feed him, also you feed.'. Also otherwise Quran counts this crime as the reason of hell fire together with some other crimes. If Erdoğan is, he rebukes and condemns socialists, and says that "where it can be seen such things socialists talk about them in the world?' by forgetting the verse in Quran called 'material values' or in the other name 'fey', that actually says all the lands are common property of the people, anyone can build own house in these lands at a suitable place free manner, can farm there also without working under the yoke of someone else by doing own lovely work. God shows reason for this as the lands shall not become the places where only rich people live there. Even Erdoğan does not thing a suitable transformation of these things. Anybody could ask Khalif Omar that where did he find such a long cloth for his new dress and how, with his share from the money? When the public could not earn so much, how could he did it? He was 2 meters in height; so actually the cloth he took as share was not enough for a new dress; so he demanded from his son being his son was willful. If Erdoğan is, he says abut his ships something like"There is an important difference between a ship and a little ship." He means "Is it United Star Ship Enterprise?". Also says that even you can start by an amount of money 100.000 dollars, and after that the ship will pay the rest. This is pretty famous and exact Islamic principle that lord feeds own slave by what the lord ate. There cannot be a slave market. If lord is rich, own slave will be fed better. At the same time, if another lord is not so rich, own slave will not be fed so much better. In Turkey, nobody can be fed like Erdoğan. Nobody can find 100.000 dollars so easy.

If Muslims show respect for Erdoğan since he is Muslim, they should know that also he has big enough sins which are not smaller than such a murder in the impact attempt. The impact attempt finished in a day; but as God says 'persecution is worse than death' in Quran, still serious problems continue that are serious at least as much as many impacts. As he did not take required precautions against these persecutions, also still he has no project satisfies. How many people die in a day because of financial reasons that we can include some moneydriven crimes such as theft, becoming drug dealer and doing women and arms trade or even can include some issues like illness. Did not say Muhammad there is no difference between a causative person and the person doing the cause?

At the end of the war emerged between Khalif Ali and a governor Muawiyah, 60 million people died there in 7th century if we edit the number for the current world population. Such an army was there in that age that now only England has in Europe. Before a war has not been broken out, Ali tried to persuade them a few times against a rebellion. Erdoğan did not try at least after the wiretapping. Also still wandering all over the world by saying 'Be careful about them. The may also realize another impact in your state.'. Ali said at the end of the war that 'Our brothers rebelled us, and we forgave them.'. Erdoğan did not say such a thing. All the leaders against Ali made a consensus after this until they die. Even Muhammad used his old enemies as head companions of him, that some of them killed many companions of Muhammad. Yes, maybe lives of Turkish people and the statesmen are so burned; but they must be fair enough in any condition. An uncle of Muhammad called Hamzah who is one of the most powerful professional warrior of his age that known as lion hunter or lion of God, was murdered and his body was shredded. There are no nose, no ear and no eye... He killed half of the enemies killed by the other companions alone during a war, and then someone shot him from a range by a ranged weapon. Muhammad was also sent to forbid crying for a death by shouting; but he also cried when he saw the corpse by shouting, and swore that he also shall kill dozens of people from them as a response. God let Joshua for a holocaust; but said to Muhammad that you cannot do it, you must be fair. God forced him to talk to his enemies and then also the enemies became Muslims, as also they became high reputable managers of Muslims. Namely, he managed his state by his old enemies.

According to me these are enough to be consoled. These men also gave advises; but when they were tested, also they stayed loyal about what they claimed before. As a result, I want to say that the people who Erdoğan follow them were tested challengingly and harder. Many times ago I heard that Erdoğan had been kept a book advises from Khalif Ali as bedside book; but it seems that Erdoğan hided the book under his bed when he saw is not applicable. Ali says that if your power was enough to defeat your enemy, then make a thank to God by forgiving your enemy.

They can make a national agreement with the prisoners. Already many free places emerged in army and in other institutions. They are experienced people. Turkish people should forgive them if they wish. Also the rebels must apologize to Erdoğan; because once a companion asked Muhammad that how should they act against a president who demands his right but gives ours. Muhammad said that in any condition, you must be patient if you do not want to die as an unbeliever. Namely, even if Erdoğan was wrong, they would not act such that. Maybe they can be used again for example in army by lowering their ranks.

In Turkey, secularism must take a different shape. Instead of the other things, a smart person should emerge and should say that 'If God scares me against punishing, and if gives orders by charging responsibilities, then this also creates a selfdefence right for me spontaneously; therefore if I think the future of my state, I turn the religion of my state into Islam but also I allow the people who want to live without religious responsibilities in a different colony even they walk without dress. If God asks me about this tomorrow why I did it in this way, I say that Muhammad said God only gave to Dhul Kharnain, Solomon and Mahdi absolute world domination in the history of mankind between Muslims; so I thought that I cannot be lucky that much. I cannot be that chosen one, that is dangerous thought. Namely we can cause trouble. Already If only three persons have absolute world domination, expansionism is not a sensible trade. You cannot make me responsible about this subject. Instead of it, I found a new method out for agreement and for the survival of the state with its all elements. I think actually by this bay, more people will know God. Even it shall provide much more possibility and freedom for unbelievers without any condition. By this way, as I created a shield against destruction of my state, also distracting and thus people will find more helpful thing to talk. This is like secularism since nobody forced to realize religious responsibilities but religious colonies naturally.' If you drive in a stake around a well for the people who want to connect horse while they drink water, God will accept it. If you do the same thing for the fall of the people into the well, God will not accept it. The same event is categorized differently.

The same is also acceptable for the entire world. Also they should take precautions in the suitable manner, and together with showing respect to each other about their wishes, also they answer them as they serve. I hope it happens; because the 
current situation seems desperate in the name of world leaders as well. Still nearly each one of ten persons is hungry in the world. If the election process of Trump is watched, it can be seen that some people were distributing some t-shirts writing 'Donald F..king Trump' on them. They were advocating by this way. If I knew Trump was born with that hair, when I saw that slogan, I would think that 'Probably it is his second name.' while dreaming his father that baby Trump is on his hands after the birth. Maybe you will say that these are personal mistakes; but according to me, these are a result of American waywardness and indifference. I think some more sensitive persons like Bill Gates would defend benefits of own nation while also are working for peace and prosperity of nations and thus the world people.

\subsection{Africa}

We should develop a project for Africa to improve their abilities as well. The United Nations should press money for African Colonies, and we can build them from today to tomorrow. They can live without any concerns about economy and the other life elements.

We can establish some colonies in Africa for the workers of Africa work about the continent carrier monsters, that I told about them the above. We can collect from all over Africa required number of the workers.

Also we need a land connection about the new home; so we if does the work, we should start to fill ocean from African sides. Even if we should start to dig from the states like Russia, Tibet and Canada by creating huge holes since we do not have enough land for more actually even if we can bring from the moon; also we can start to lift that earth shapes changes the the climate of Africa into a bad condition. As water level will increase even if actually at the and of the work it will again decrease since the holes will be filled by water, first of all we must move coastal people that the countries like Japan and Holland must have priority about this subject. They quickly will take place after each part of the filling. They will not build anything which cannot be moved. Mobility is important. At the end of the work, we decide the actual places by draw even for each colony. By this way, each colony of a state may have foreign different neighbours.

Two particle accelerators wind around the earth would not be bad for the both continental; so we should start building them together with the filling.

\section{Conclusion}

As it can be seen, there is a building which is actually based on economy. There are some basic and superficial offers about perfection of our life, since basic functions must give healthy results by the same labor. This building counts states as local governances as a requirement of one world order; does not stipulate working and military service; promises that no charge for houses, energy, education, judgment, security, health care, public transport, marriage; promises removing armies limited manner, removing nuclear weapons and establishing in space but some special conditions. People can live without worries about the future. Just we will make a good planning by required placement to gain experience before about our work.

As a result of this discussing, self-running management system seems as possible for today and future. We made the car's tires as polygon has enough sides for the current situation; but henceforth I just say, that let's roll.
This is the third version of the paper. There were some grammatical mistakes. Sorry about this.

I shall not claim patent right. Anybody who wants to use the above stated information can use freely without asking.

I accept any sanction if there is a lie about the things which I claimed in the text about current social problems. Already most of them are pretty famous; but even so I shall add references soon.

\section{References}

1. Kavak M. 2018, Complement Inferences on Theoretical Physics and Mathematics, OSF Preprints, Available online: https://osf.io/tw52w/

2. Kavak M. 2016, On the Uncertainty Principle, American Journal of Physics and Applications, Vol. 4, No. 4, 2016, pp. 90-123. Available online: https://osf.io/t8zqw/

\section{Acknowledgement}

